\title{
Tissue sparing, behavioral recovery, supraspinal axonal sparing/regeneration following sub-acute glial transplantation in a model of spinal cord contusion
}

\author{
Helen R Barbour ${ }^{2}$, Christine D Plant ${ }^{1}$, Alan R Harvey ${ }^{3}$ and Giles W Plant ${ }^{1,2^{*}}$
}

\begin{abstract}
Background: It has been shown that olfactory ensheathing glia (OEG) and Schwann cell (SCs) transplantation are beneficial as cellular treatments for spinal cord injury (SCI), especially acute and sub-acute time points. In this study, we transplanted DsRED transduced adult OEG and SCs sub-acutely (14 days) following a T10 moderate spinal cord contusion injury in the rat. Behaviour was measured by open field (BBB) and horizontal ladder walking tests to ascertain improvements in locomotor function. Fluorogold staining was injected into the distal spinal cord to determine the extent of supraspinal and propriospinal axonal sparing/regeneration at 4 months post injection time point. The purpose of this study was to investigate if OEG and SCs cells injected sub acutely (14 days after injury) could: (i) improve behavioral outcomes, (ii) induce sparing/regeneration of propriospinal and supraspinal projections, and (iii) reduce tissue loss.
\end{abstract}

Results: OEG and SCs transplanted rats showed significant increased locomotion when compared to control injury only in the open field tests (BBB). However, the ladder walk test did not show statistically significant differences between treatment and control groups. Fluorogold retrograde tracing showed a statistically significant increase in the number of supraspinal nuclei projecting into the distal spinal cord in both OEG and SCs transplanted rats. These included the raphe, reticular and vestibular systems. Further pairwise multiple comparison tests also showed a statistically significant increase in raphe projecting neurons in OEG transplanted rats when compared to SCs transplanted animals. Immunohistochemistry of spinal cord sections short term (2 weeks) and long term (4 months) showed differences in host glial activity, migration and proteoglycan deposits between the two cell types. Histochemical staining revealed that the volume of tissue remaining at the lesion site had increased in all OEG and SCs treated groups. Significant tissue sparing was observed at both time points following glial SCs transplantation. In addition, OEG transplants showed significantly decreased chondroitin proteoglycan synthesis in the lesion site, suggesting a more CNS tolerant graft.

Conclusions: These results show that transplantation of OEG and SCs in a sub-acute phase can improve anatomical outcomes after a contusion injury to the spinal cord, by increasing the number of spared/regenerated supraspinal fibers, reducing cavitation and enhancing tissue integrity. This provides important information on the time window of glial transplantation for the repair of the spinal cord.

Keywords: Transplantation, Tissue sparing, Behavioral recovery, Spinal cord injury, Glia

\footnotetext{
* Correspondence: gplant@stanford.edu

'Department of Neurosurgery, Stanford Partnership for Spinal Cord Injury and Repair, Stanford University, Lorry I Lokey Stem Cell Research Building, 265 Campus Drive, Stanford, CA 94305, USA

${ }^{2}$ Eileen Bond Spinal Research Center, University of Western Australia, Perth, Australia

Full list of author information is available at the end of the article
} 


\section{Background}

In models of spinal cord injury (SCI), transplantation of growth-permissive tissues and cells has been performed to provide trophic support for damaged neurons and to transform the inhibitory milieu of the lesion site; this allows axons to grow through the otherwise impenetrable glial scar or cystic cavity. Olfactory ensheathing glia (OEG) facilitate the growth of newly-generated olfactory sensory axons into the olfactory bulb in normal adults [1-4] and after olfactory nerve section $[5,6]$. These cells have the potential to facilitate repair after injury, and their potential to enhance tissue repair has been extensively tested in experimental SCI models [7-14]. Schwann cell (SCs) grafts also have the ability to promote axonal regeneration following peripheral and CNS injuries [14-18], and as such were used in this study to compare the outcomes achieved using OEG in sub-acute spinal cord injury model.

Standard methods for isolating adult rat and human SCs have been developed, which result in a homogenous population of cells with stable characteristics [19-22]. However, methods to both isolate the OEG and transplant the OEG vary considerably, as do the experimental results. OEG display considerable morphological plasticity in vitro, changing phenotype within hours after changes in culture conditions [23-26]. Despite this, consistent functional and anatomical improvements have been obtained using olfactory bulb-derived p75-purified OEG from adult inbred rats [8-11,13,27]; results with lamina propriaderived OEG are less consistent [28-30].

To initially identify transplanted OEG and SCs, immunohistochemistry using an antibody to low affinity nerve growth factor receptor (p75) was used. However this approach is problematic, because it cannot unequivocally distinguish between transplanted OEG and SCs from endogenous SCs, which may enter the spinal cord via dorsal root entry zones or blood vessels [21,31-33]. Detection of p75 can sometimes be unreliable, as its ligand-binding domain can be cleaved in vivo and in vitro by endogenous proteases [34,35]. For this reason, lentiviral ex-vivo prelabeling $[12,26,36]$ of OEG and SCs with DSRED-2 was also used in this study. This allowed the quantification of surviving grafted cells, the analysis of their distribution and influence on endogenous spinal cord cells and axons, and assessment of their impact on matrix deposition and the host repair process.

We hypothesized that transplants of adult OEG or SCs may differ in their ability to promote axonal sparing/ regeneration $[4,37]$ and that a delayed transplant at 14 days post injury would improve anatomical and functional outcomes following a spinal cord contusion. This experimental study is based on numerous years of research into both glial types in CNS injuries, including the spinal cord. This time point was chosen because: (i) it represents a realistic time window deliver this type of cellular therapy in a clinical trial. This time period also gives consideration for time needed to generate and purify sufficient autologous OEGs for transplantation into injured patients, stabilization surgery and an optimal time window for best outcomes [38], (ii) experimental data from previous animal studies indicate that delayed transplantation may be more beneficial for cell survival, integration and reduced immune mediated rejection $[8,14,20,38-41]$, and (iii) after 15 days in vivo a significant scar forms that may inhibit cell integration and axonal regeneration [38]. In support of this time point, 14 days was the time point chosen for the recent oligodendrocyte precursor and activated macrophage clinical trials. It should also be noted that the term "sparing/regeneration" has been used in relation to the analysis of axonal growth within this manuscript; this is because as described previously in a contusion model study [8] using fluorogold, we cannot truly distinguish between spared and regenerated axons.

\section{Results}

Cell transplantation is associated with improved retention of tissue at the lesion site

All experimental groups exhibited loss of tissue at the lesion site following the initial contusion injury (Figure 1). Morphological analysis involved measuring the total amount of residual tissue; this included intact tissue, as well as the remaining graft and other degenerate/regenerate tissue that could not be classified as white or grey matter. The total tissue remaining included degenerate/regenerate tissue and the cellular trabeculae between cysts, lesion site and grafted cells. Tissue integrity classification was determined by Nissl gold myelin staining, which allows distinction between intact and non-intact tissue containing macrophages. The extent of the injury/transplant zone was also identified by the use of GFAP immunostaining, which allows the area of intact spinal cord versus the cyst areas to be defined. On the day of transplantation (i.e. 2 weeks post initial SCI), the total spinal cord tissue remaining was $88.4 \pm 8.0 \%$ of uninjured spinal cord and the amount of remaining intact tissue was $55.4 \pm 12.8 \%$ (mean \pm s.e.m).

Two weeks following cell SCs transplantation (OEG or $\mathrm{SCs}$ ), there were no significant differences between groups in the amount of total tissue $(\mathrm{p}=0.27)$, with $72.4 \pm 3.7 \%$ > $(\mathrm{n}=6)$ of normal in the medium-injected group, $74.6 \pm 9.2 \%$ $(\mathrm{n}=6)$ in the OEG-transplanted group and $85.1 \pm 2.9 \%(\mathrm{n}=6)$ in the SCs-transplanted group. Similarly, there were no significant differences $(\mathrm{p}=0.25)$ between groups for intact tissue remaining, which was $29.5 \pm 4.6 \%(\mathrm{n}=6)$ of normal in the medium-injected group, $38.9 \pm 7.7 \%(\mathrm{n}=6)$ in the OEG-transplanted group and $41.6 \pm 2.3 \%(n=6)$ in the SCs-transplanted group. 


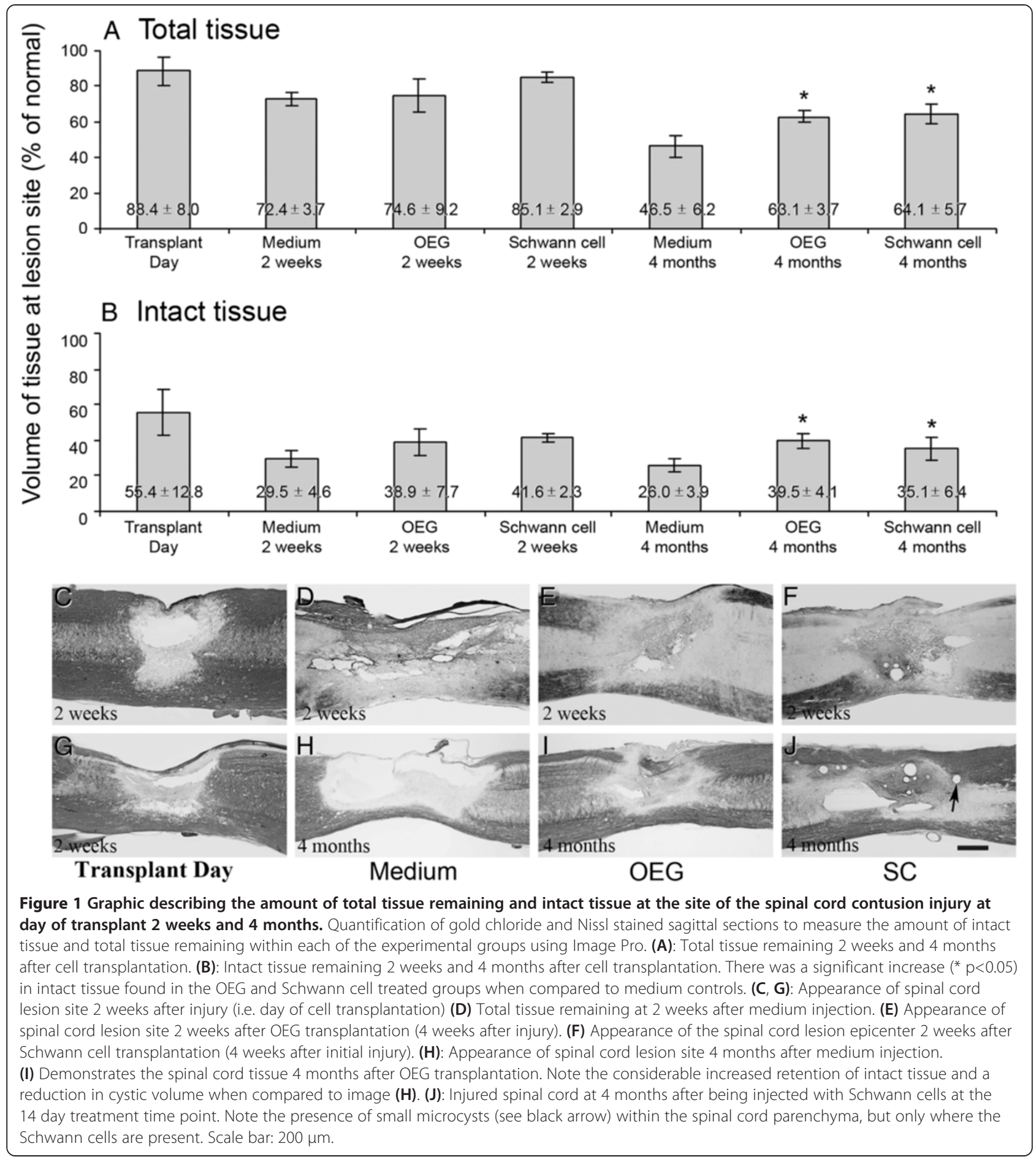

It was not until the 4 month time point that total tissue in the transplanted groups was found to be significantly greater than controls $(\mathrm{p}=0.028)$. Total tissue was $46.5 \pm 6.2 \%(n=11)$ of uninjured spinal cord tissue in the medium-injected group, $63.1 \pm 3.7 \%(\mathrm{n}=11)$ in the OEGtransplanted group and $64.1 \pm 5.7 \%(\mathrm{n}=11)$ in the SCs- transplanted group. A significant difference $(\mathrm{p}=0.028)$ was also seen between groups at 4 months in the amount of intact tissue remaining, which was $26.0 \pm 3.9 \%(\mathrm{n}=11)$ of normal in the medium-injected group, $39.5 \pm 4.1 \%(\mathrm{n}=11)$ in the OEG-transplanted group, and $35.1 \pm 6.4 \%$ in the SCs-transplanted group (Figure 1A, B). 


\section{Nissl staining/gold chloride staining}

Spinal cord sections visualized with Nissl staining showed good preservation of spinal tissue. Cysts that were present were frequently small (see Figure 1D,E and F) and very few in number. As mentioned above, no difference in tissue survival was noted in any of the control or transplanted groups (OEG or SCs). Nissl gold myelin staining at 4 months showed a reduction in tissue loss, particularly the reduction in cyst volume and sparing of white and grey matter within the lesion zone (see Figure $1 \mathrm{H}, \mathrm{I}$ and J). The presence of round microcysts was noticeable in the spinal cords of SCs treated rats, and were present in 2 week and 4 month spinal cords; neither OEG transplanted rats or control (medium injected) rats showed these cysts.
Transgene expression, cell dispersal and survival of transplanted Schwann cells and OEG

Approximately 92\% of OEG and 99\% of SCs were labeled in vitro (as a total of all Hoechst 33342 labeled cells) (Figure 2A and B). OEG or SCs were not previously transduced with self inactivating lentiviral-DSRED-2 vectors. This vector was found to be non-toxic (data not shown) and enabled visualization of cytoplasmic spread and cellular morphology for up to 4 months post-transplantation into the CNS. DSRED-2's stability and capacity to track cells was determined to be as efficient as seen previously with GFP [12,26,36,42]. DSRED-2 labeled showed no additional immunological response in vivo when compared to the GFP transgene which may occur with LacZ [43] or human placental alkaline phosphatase [44].
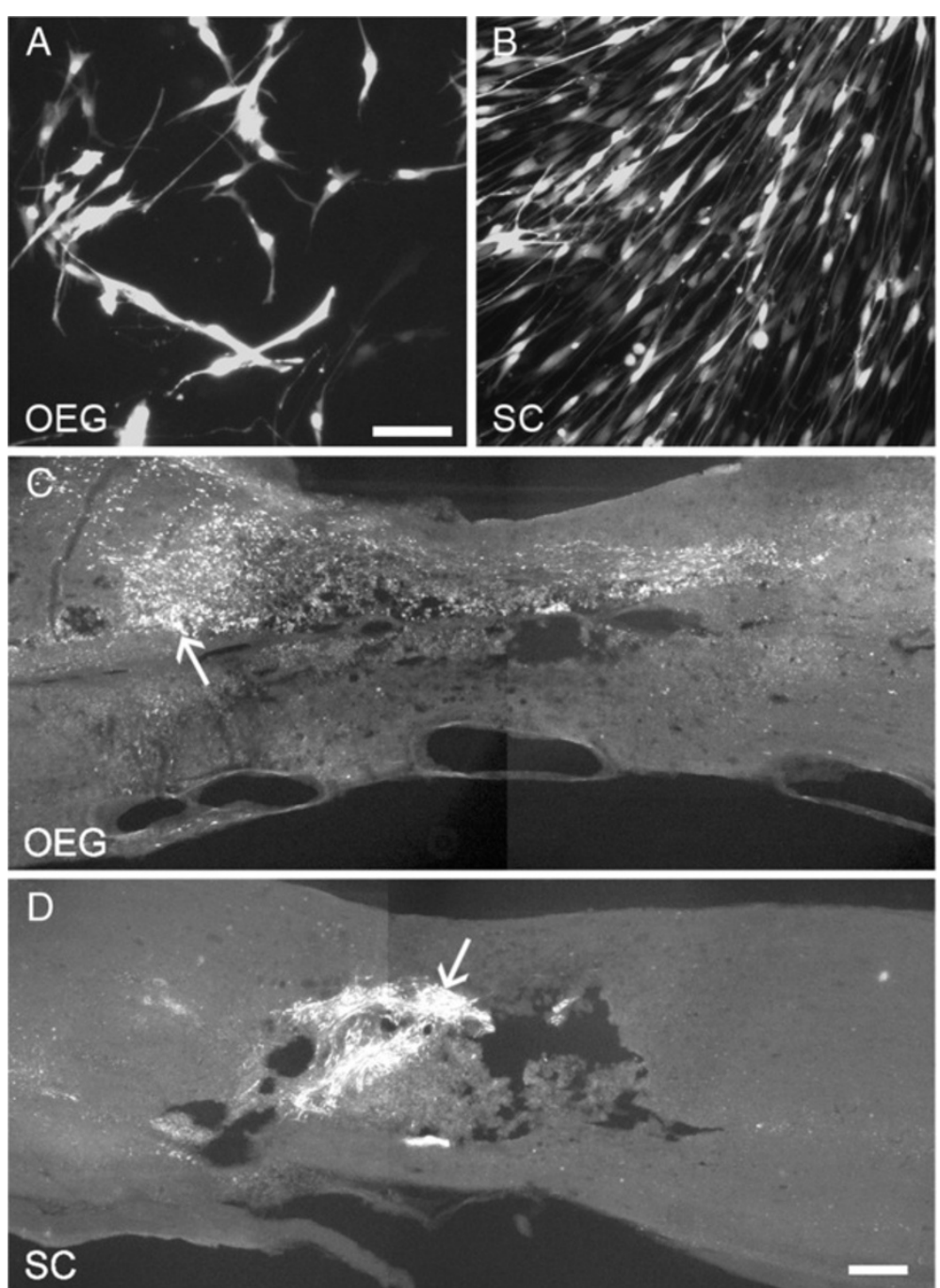

Figure 2 Photomicrographs representing lentiviral transduced and transplanted OEG and Schwann cells. A: OEG in vitro labeled with lentiviral DsRed2. B: Schwann cells in vitro labeled with lentiviral DsRed2. Scale bar (A B): 50 m. C D: Localization of transplanted OEG (C) and Schwann cells (D) within the spinal cord lesion site 2 weeks after transplantation. Schwann cells appear to have survived in greater numbers than the OEG. However, OEG are more dispersed through the spinal cord tissue while Schwann cells remain in a dense aggregate. Scale bar (C D): $100 \mu \mathrm{m}$. 
Figures 2C and D show representative spinal cord sagittal sections with OEG and SCs grafts 2 weeks following cell transplantation. Lentiviral-DSRED-2 labeled OEG was detected in all but one of the animals whereas lentiviral-DSRED-2 labeled SCs was detected in all animals. At 2 weeks after transplantation to the injured spinal cord, DSRED-2 fluorescence pixel intensity for surviving transplanted OEG was $70 \pm 29$ at the rostral aspects of the transplant/lesion zone, versus $91 \pm 37$ for SCs, at the center of the lesion $86 \pm 35$ for OEG and $100 \pm 41$ for SCs. Lastly the DSRED-2 fluorescence pixel intensity at the caudal edge of the transplant/lesion was $83 \pm 34$ for OEG and $79 \pm 32$ for SCs. In rats at 2 weeks ( $n=6$ per group) analyzed, detectable transplanted OEG had in some cases dispersed up to $5 \mathrm{~mm}$ from the center of the injection site, the furthest distance measured. In contrast, DSRED-2 positive transplanted SCs were highly localized to the site of injection, dispersing no more than $0.6 \mathrm{~mm}$ from the injection site. At 2 weeks post transplantation the surviving OEG were dispersed throughout the lesion site and adjacent spinal cord tissue, and were aligned along the rostrocaudal axis of the spinal cord. SCs were densely packed, with an alignment that was highly regular within the graft area but did not disperse into the intact host CNS tissue surrounding the lesion site.

Four months after OEG transplantation, DSRED-2 positive OEG were detected in 7 out of 11 animals (64\%) whereas DSRED-2 positive SCs were detected in 11 out of 11 animals (100\%). Measurements of DSRED2 fluorescence pixel intensity showed OEG at the rostral part of the lesion at $22 \pm 9$ and SCs $34 \pm 14$, at the center of the lesion the values were $21 \pm 9$ for OEG and $29 \pm 12$ for SCs. DSRED-2 pixel fluorescence was found to be $19 \pm 8$ for OEG at the caudal part of the lesion and $28 \pm 12$ for SCs. As estimated from the DSRED-2 fluorescence, the levels of OEG present within the spinal cord had decreased throughout the rostral-caudal axis of the lesion by $74 \%$ at 4 months from the value seen at 2 weeks post transplantation. At the same time DSRED-2 fluorescence pixel values for SCs reduced from 2 weeks and 4 months, however fluorescence levels were significantly higher than OEG levels $(\mathrm{p}<0.05)$ (see Additional file 1: Table S1).

\section{Scar formation, CS56 synthesis and gliosis}

Deposition of proteoglycan scar/inhibitory molecules was assessed in transplanted OEG, SCs, and control medium injected spinal cords by immunofluorescence section staining with antibodies to GFAP and CS56 (for chondroitin sulphate proteoglycans). The extent of staining was assessed across the lesion site in a rostro-caudal direction. After 2 weeks post transplantation, OEG spinal cords showed a moderate change in GFAP staining when compared to SCs and medium treated spinal cords $(n=6$ (Figure 3A,C). In particular, this was noted at the caudal aspect of the transplant zone (Figure 3B,D). At 4 months following OEG, SCs and medium injections, GFAP immunofluorescence staining (analyzed by pixel intensity) revealed a trend towards a lower degree of GFAP immunofluorescence at the injury zone. The OEG transplanted group showed a reduction of $27 \%$ in GFAP immunofluorescence when compared to the SCs transplanted group and a $23 \%$ reduction in GFAP immunofluorescence when compared to the medium-injected group. However, this difference was not statistically significant $(\mathrm{p}<0.05)$.

Integration of transplanted cells with host astrocytes was frequent for the OEG transplant groups but infrequent for the SCs transplant animals. CS56 proteoglycan staining was analyzed across the OEG, SCs and medium groups in the 4 month post transplant spinal cords $(n=11)$. Immunofluorescence staining for CS56 in the SCs transplanted group (Figure $3 \mathrm{E}$ ) was significantly greater than medium injected control sections $(\mathrm{p}<0.001)$ (Figure $3 \mathrm{~F}$ ) and the CS56 immunofluorescence was greater in the SCs group compared to the OEG transplanted group $(\mathrm{p}<0.01)$ (Figure 3F). CS56 immunofluorescence in the OEG group was not significantly different from the levels seen in the medium injected controls.

\section{Extracellular matrix deposition within the lesion site}

At 4 months post injury, the grey and white matter bordering the lesion site contained numerous blood vessels, the walls of which were highlighted by laminin-1 staining (Figure 4A,B,D-K). The dura mater was strongly immunoreactive for laminin-1 in all analyzed spinal cords. In addition to the meningeal and vascular-associated laminin-1, the graft sites of OEG and SCs grafts also contained laminin-1. Compared to the medium injected control group, the laminin-1-stained area appeared more extensive in both the OEG and SCs transplanted groups, but these differences were not statistically significant $(\mathrm{p}=0.15)$. At higher magnification, it was observed that areas strongly immunoreactive for laminin-1 co-existed with the DSRED-2 positive cells only in the SCs transplanted group (see Figure 4I,J,K vs. E,F,G). Frequently, the areas of strong laminin-1 immunoreactivity in OEG grafted spinal cords were not associated with the location of surviving DSRED-2 positive transplanted cells, indicating another source or cell type such as endothelial cells for the laminin-1. Laminin-1-positive structures around bundles of axons in both the OEG and SCs transplanted groups were observed.

The profile of immunoreactivity for collagen IV (Figure 4C and L-S) was similar to that observed for laminin-1. Structures resembling blood vessels were visible around the site of the spinal cord lesion in the OEG transplanted group (Figure 4L). While the graft site of the OEG transplanted group contained more collagen IV immunofluorescence than that of the other 

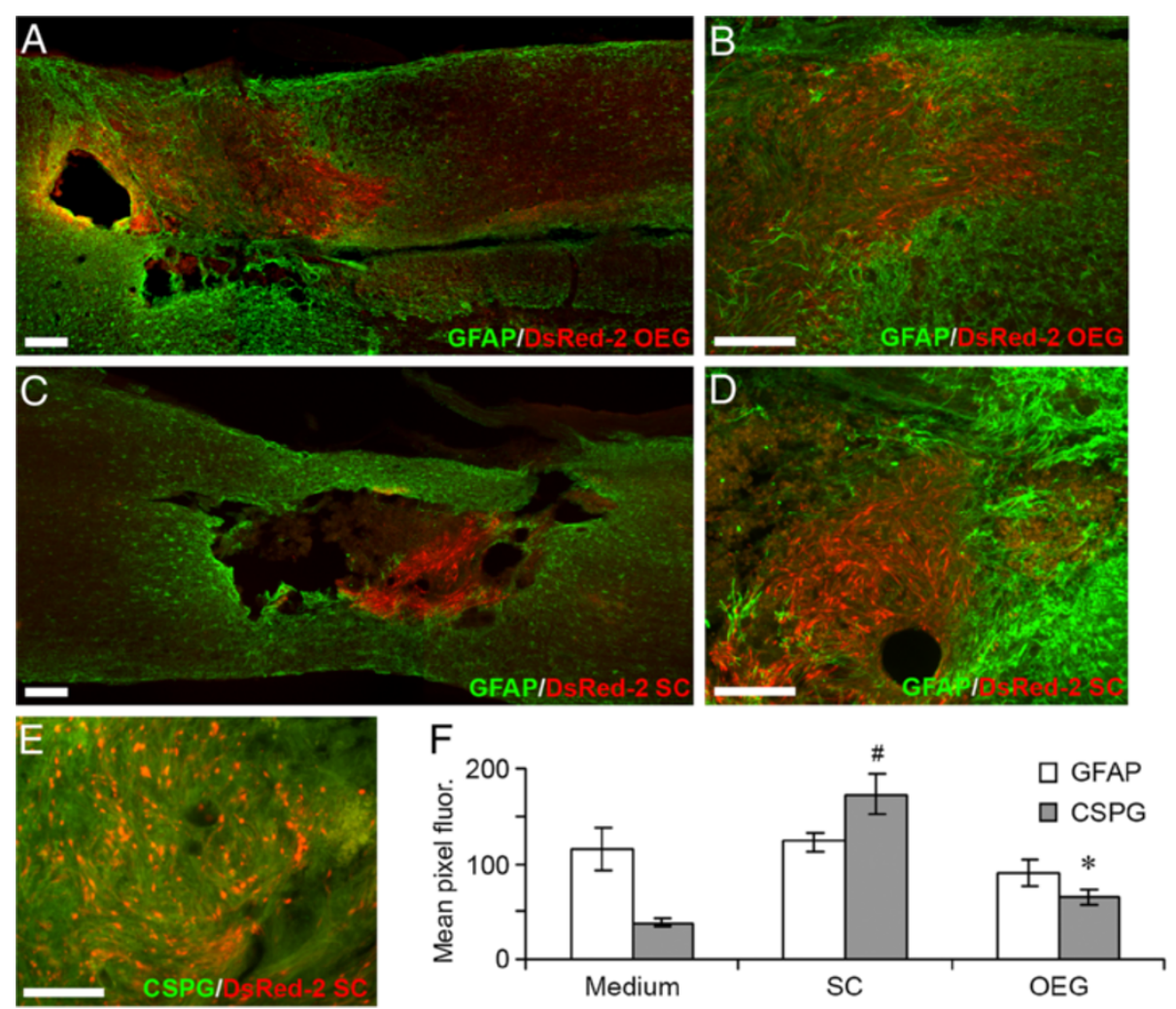

Figure 3 Glial scar formation at the lesion site indicated by GFAP and CSPG immunoreactivity. A-D: GFAP in green DsRed2-labeled transplanted cells in red. A-B: Lesion site 2 weeks after transplantation of OEG. C-D: Lesion site 2 weeks after transplantation of Schwann cells. Dispersal of transplanted cells is greater for OEG than for Schwann cells. Schwann cells remain in a dense aggregate at the lesion site surrounded by strong GFAP immunoreactivity. E: Schwann cells are surrounded by dense proteoglycan network CSPG (green), DsRed2-labeled transplanted cells (red). Scale bars: A-D: $100 \mu$ m, E: $200 \mu \mathrm{m}$. F: Graph showing the quantitative fluorescence (measured by mean pixels) of GFAP and CSPG at the distal interface of the transplant zone ( $n=10$ for each group). OEG had significantly less ( $<<0.05)$ CSPG expression when compared to Schwann cells (see*). Schwann cells had significantly greater $(p<0.05)$ CSPG expression when compared to medium injected controls (see \#).

groups (Figure 4L and $\mathrm{P}$ vs. C), measurement using pixel intensity revealed the collagen IV immunofluorescence for each group to be statistically similar $(\mathrm{p}=0.10)$. As with laminin-1, at higher magnification, collagen IV could be seen in high quantities in regions of the SCs grafts. However in the OEG transplanted group high amounts of collagen IV appeared to originate from DSRED-2 negative cells in the vicinity of the DSRED-2 positive cells (Figure 4O,S), which may represent either endogenous SCs invading from the periphery or host endothelial cells.

\section{Axonal profiles inside lesion site}

Immunohistochemistry with the neurofilament-specific antibody RT-97 was used to estimate the presence of medium and high neurofilament-containing axons in and around the lesion site of all transplanted groups and controls (Figure 5). At the lesion epicenter of all groups, continuous white matter tracts of spared axons could be seen at the ventral edges of each section (Figure 5A,B, and D). Dorsal white matter tracts were in an improved state of preservation after OEG and SCs transplants. In addition, $\mathrm{RT} 97^{+}$axons were present in the lesion site in all transplanted and control groups with $\mathrm{RT} 7^{+}$axons being co-extensive with DSRED-2 OEG and SCs (Figure 5E). Axons entering SCs graft areas or putative graft areas, were commonly observed to lose rostral-caudal directionality and instead aligned with the random internal organization of the graft (Figure 5E). However this nonlinear pathway for axons was not seen in the OEG transplanted spinal cords (Figure 5C).

\section{Evidence for infiltration of endogenous Schwann cells into the spinal cord}

In several of the OEG or SCs transplanted animals, the lesion site contained numerous fascicles of cells with glial-like spindle-shaped morphology; these cells were positive for p75 but negative for DSRED-2. Sections from the medium-injected group also contained p75-positive cells both at 2 weeks and 4 months after transplant day (Figure 6A,B). The p75-positive cells in the OEG (Figure 6C and D) and SCs (Figure 6E,F) transplant 

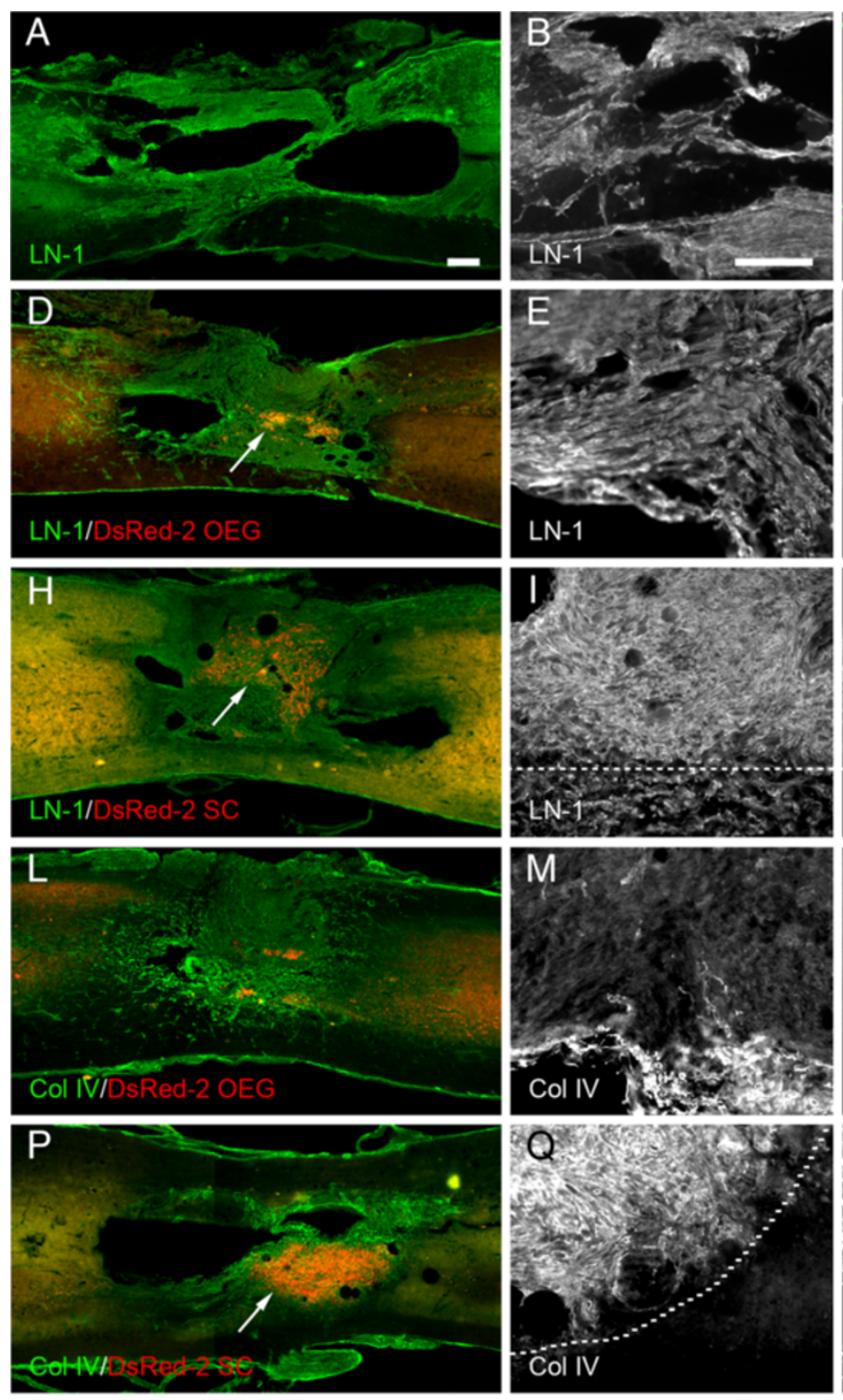

Figure 4 Schwann cell, OEG and medium treated spinal cords at 4 months. Photomicrographs depicting the distribution and immunoreactivity for laminin-1 (A, B, D-K) and collagen IV (C, L-S) at the site of spinal cord contusion lesion with or without the transplantation of SCs and OEG. Areas of strong immunoreactivity for laminin can be seen to surround the areas of the transplanted cells (see arrow in $\mathbf{D}$ depicting DsRed-2 OEG). Laminin immunostaining does not appear to be co-localized on the surface of the OEG cells (see arrows in G). Laminin is also found surrounding Schwann cell transplants (see $\mathbf{H}$ ). Arrow depicts the central core of the transplant. Laminin is very strong in the region of the Schwann cells (see I-J) with the host spinal cord below the dashed line has reduced intensity of staining. Collagen IV immunostaining depicts a central core of staining close to the lesion site surrounding any surviving OEG (see $\mathbf{L}$ ) but labeled cells (see arrows in $\mathbf{0}$ ) are not colabeled with collagen IV. Collagen IV immunostaining in Schwann cell transplanted spinal cords show intense staining surrounding and within the DsRed-2 SC transplant area (see arrow). In higher power the staining is mostly co-localized (see above dashed line) but some areas are not. Scale bars: $100 \mu \mathrm{m}$. Scale bar in A also serves C, D, H, L and $\mathbf{P}$. Scale bar in B also serves $\mathbf{E}, \mathbf{F}, \mathbf{I}, \mathbf{J}, \mathbf{M}, \mathbf{N}, \mathbf{Q}$ and $\mathbf{R}$.

groups may have been donor cells that were not expressing the DSRED-2 transgene. It is also possible that SCs had migrated into the spinal cord from blood vessels within the spinal cord or via the dorsal roots [45]. The latter is more likely, because the method using lentiviral vectors encoding transgene such as GFP have previously been shown to display long term expression [12] and these p75-positive cells were also detected in the medium-injected groups.

\section{Numbers of retrogradely labeled descending axons} increased by glial transplantation

Retrograde labeling with Fluorogold was used to quantify extension of spared/regenerated descending supraspinal 

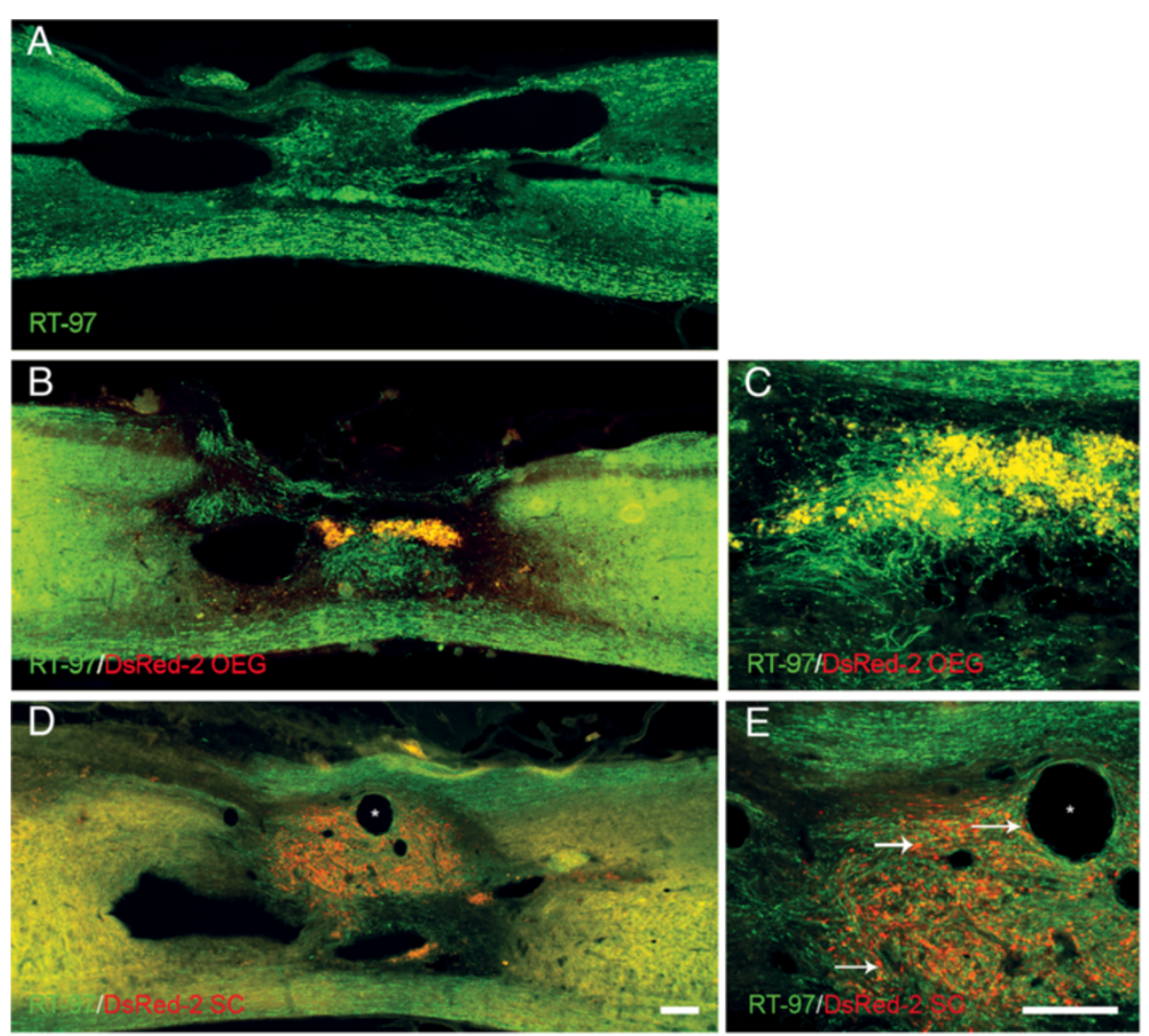

Figure 5 Axonal staining at the lesion site of Schwann cell, OEG and medium groups. Immunoreactivity for RT-97 at the site of spinal cord contusion 4 months after medium (A) OEG (B-C) and Schwann cells (D-E) transplantation. RT97 positive axons are observed within the lesion site in all groups but number and distribution varied. Axons in the OEG group (B) were arranged in fascicular bundles but did not have rostral to caudal orientation unlike axons beneath the graft area which constitute the ventral white matter. See (C) for higher power image of

(B). RT97 staining after Schwann cell transplantation (see D). These axons showed a close association with DsRed-2 positive cells but followed a non linear path. Arrows in (E) depict DsRed-2 labeled Schwann cells deep within the transplants or close to microcysts $\left(^{*}\right)$. Scale bars: $100 \mu \mathrm{m}$.

Scale bar in $\mathbf{D}$ also serves $\mathbf{A}$ and $\mathbf{B}$ scale bar in $\mathbf{E}$ also serves $\mathbf{C}$.

axons reaching $8 \mathrm{~mm}$ beyond the most caudal edge of the contusion site. Mean \pm standard errors of numbers of descending Fluorogold-labeled cells are presented. There were statistically significant differences $(p<0.05)$ between the total brain counts of the OEG transplanted group (3019 \pm 216$)$ and also the SCs transplanted group $(2767 \pm 411)$ when compared to the control injury only group (1204 \pm 331$)$.

Statistical differences $(\mathrm{p}<0.05)$ were seen in a number of separate brain regions projecting distally through the injury zone. OEG transplanted rats showed statistically significant differences in the Raphe projecting neurons (562 \pm 43$)$ compared to controls (184 \pm 62 ). Numbers of Fluorogold neurons in the Raphe for SCs transplanted rats (296 \pm 50$)$ did not show significant differences when compared to control injuries only. Rubrospinal Fluorogold numbers in the OEG and SCs grafted groups were similar $(243 \pm 34$ and $244 \pm 50$ respectively) and not statistically significantly different from the control injury only group $(115 \pm 42)$. The numbers of Fluorogold labeled neurons in the hypothalamus were significantly higher in both the OEG and SCs groups ( $135 \pm 16$ and $116 \pm 23$ respectively) when compared to controls $(60 \pm 15)$. Fluorogold labeled neurons in the reticular formation in control injury only rats numbered $632 \pm 165$, as compared to $1590 \pm 100$ for OEG treated rats and $1635 \pm 23$ for SCs grafted animals (Table 1 and Figure 7). Fluorogold numbers in the trigeminal/DC were not statistically significantly different in all groups (Table 1 and Figure 7). This was also the case for corticospinal layer $\mathrm{V}$ neurons whose axons rarely seen to project into the distal spinal cord $(8 \mathrm{~mm})$ fluorogold injection site (Figure 7). Finally, neurons labeled in the vestibular system were significantly increased in the OEG and SCs transplanted rats $(373 \pm 65$ and $360 \pm 51$ respectively) when compared to control injury only rats $(117 \pm 27)$.

\section{Schwann and OEG cell grafts increase the number of spared/regenerated propriospinal neurons}

Fluorogold propriospinal neurons were counted from spinal cord segments rostral to the lesion/transplantation 


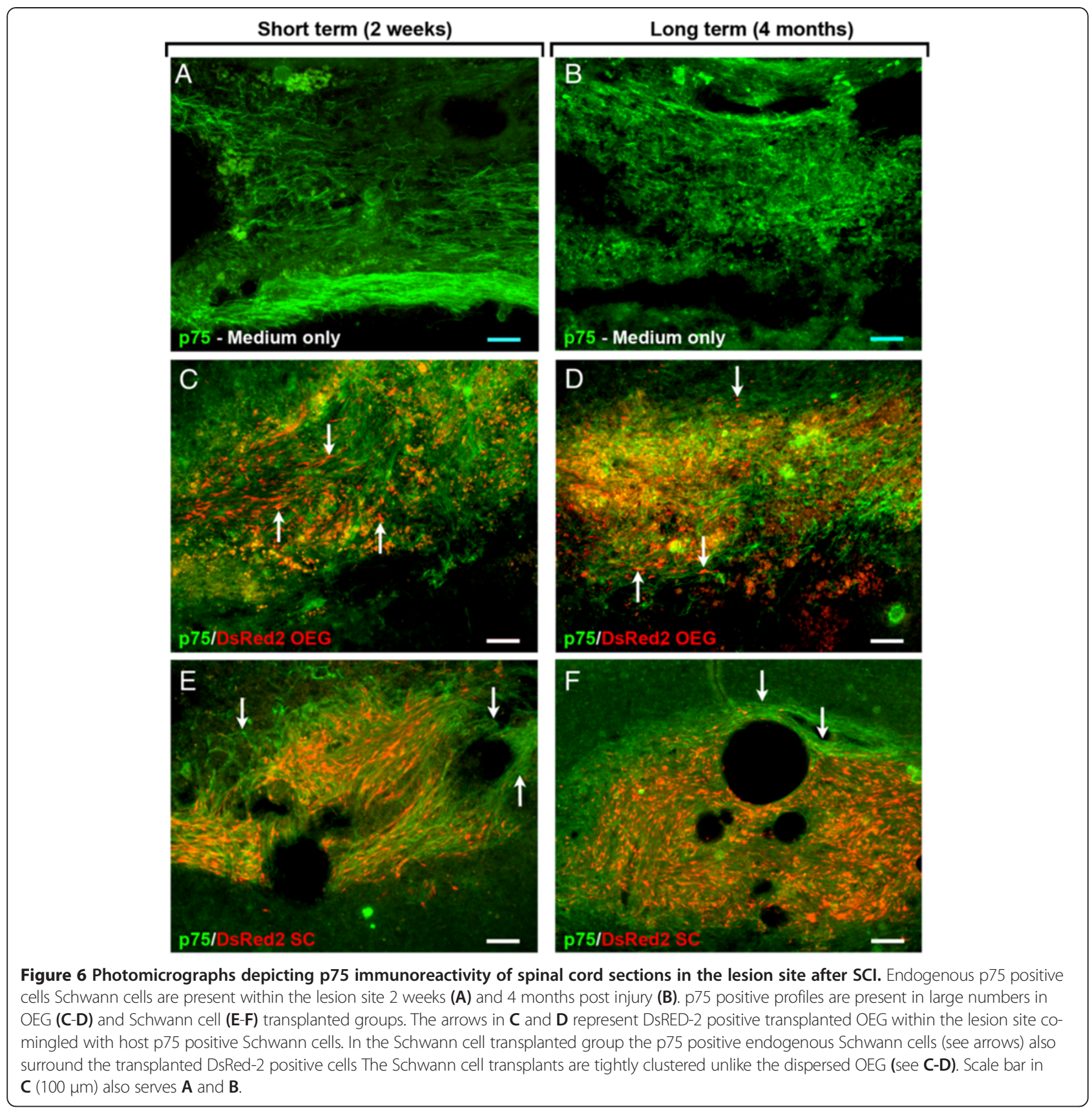

site (see schematic in Figure 8A). Propriospinal neurons that had reached the caudal injected Fluorogold ( $8 \mathrm{~mm}$ caudal from the caudal borders of the injury site) numbered $6 \pm 3$ in the medium injected group $38 \pm 26$ in the OEG transplanted group and $131 \pm 59$ in the SCs transplanted group (see Figure $8 \mathrm{~B}$ ). As seen in Figure 8 there was a significant difference between the medium injected and OEG transplanted groups, but a significantly larger number of labeled propriospinal neurons was observed in the SCs group as compared to the medium injected group $(\mathrm{p}<0.03)$. There was no statistically significant difference between the OEG and SCs transplanted groups.

Functional recovery: open field behavioral testing (BBB) and Ladder walk testing

At two weeks after injury and again at two weeks after transplantation, rats in all groups had regained bladder function. Open field behavioral scoring indicated no statistically significant changes in the BBB scores in all groups before transplantation (Figure 9). One week following transplantation of OEG or SCs (i.e. 21 days 
Table 1 Retrogradely Fluorogold-Labeled Neurons in Control, OEG Transplanted and SC Transplanted groups

\begin{tabular}{|c|c|c|c|c|c|c|c|c|c|c|c|c|c|}
\hline & $\begin{array}{l}\text { Total } \\
\text { brain }\end{array}$ & $\begin{array}{l}\text { Reticular } \\
\text { formation }\end{array}$ & $\begin{array}{l}\text { Percent } \\
\text { total }\end{array}$ & Hypothalamic & $\begin{array}{c}\text { Percent } \\
\text { total }\end{array}$ & $\begin{array}{l}\text { Vestibular } \\
\text { complex }\end{array}$ & $\begin{array}{c}\text { Percent } \\
\text { total }\end{array}$ & $\begin{array}{l}\text { Raphe } \\
\text { nuclei }\end{array}$ & $\begin{array}{c}\text { Percent } \\
\text { total }\end{array}$ & Rubrospinal & $\begin{array}{c}\text { Percent } \\
\text { total }\end{array}$ & $\begin{array}{c}\text { Trigeminal/ } \\
\text { DC }\end{array}$ & $\begin{array}{c}\text { Percent } \\
\text { total }\end{array}$ \\
\hline $\begin{array}{l}\text { Contusion } \\
\text { only }\end{array}$ & $1204 \pm 331$ & $632 \pm 165$ & 53 & $60 \pm 15$ & 5 & $117 \pm 27$ & 10 & $184 \pm 62$ & 15 & $115 \pm 42$ & 10 & $88 \pm 30$ & 7 \\
\hline $\begin{array}{l}\text { Medium } \\
\text { only }\end{array}$ & $1068 \pm 79$ & $624 \pm 62$ & 58 & $53 \pm 6$ & 5 & $113 \pm 12$ & 11 & $134 \pm 15$ & 13 & $75 \pm 15$ & 7 & $64 \pm 11$ & 6 \\
\hline $\begin{array}{l}\text { OEG } \\
\text { treatment }\end{array}$ & $3019 \pm 216^{\#}$ & $1590 \pm 100^{\#}$ & 53 & $135 \pm 16^{\#}$ & 4 & $373 \pm 65^{\#}$ & 12 & $562 \pm 43^{\#}$ & 19 & $243 \pm 34$ & 8 & $106 \pm 17$ & 4 \\
\hline SC treatment & $2767 \pm 411^{\#}$ & $1635 \pm 23^{\#}$ & 59 & $116 \pm 23^{\#}$ & 4 & $360 \pm 51^{\#}$ & 13 & $296 \pm 50$ & 11 & $244 \pm 50$ & 9 & $106 \pm 26$ & 4 \\
\hline
\end{tabular}

"The contusion only groups received a moderate contusion injury. Fourteen days after injury, OEG or Schwann cells were transplanted into the lesion site; controls received an injection of cell culture medium. Data are presented as means \pm SEM.

"Significantly different from the contusion only group, as determined by ANOVA plus Dunnett's $t$ test; $p<0.05$. 


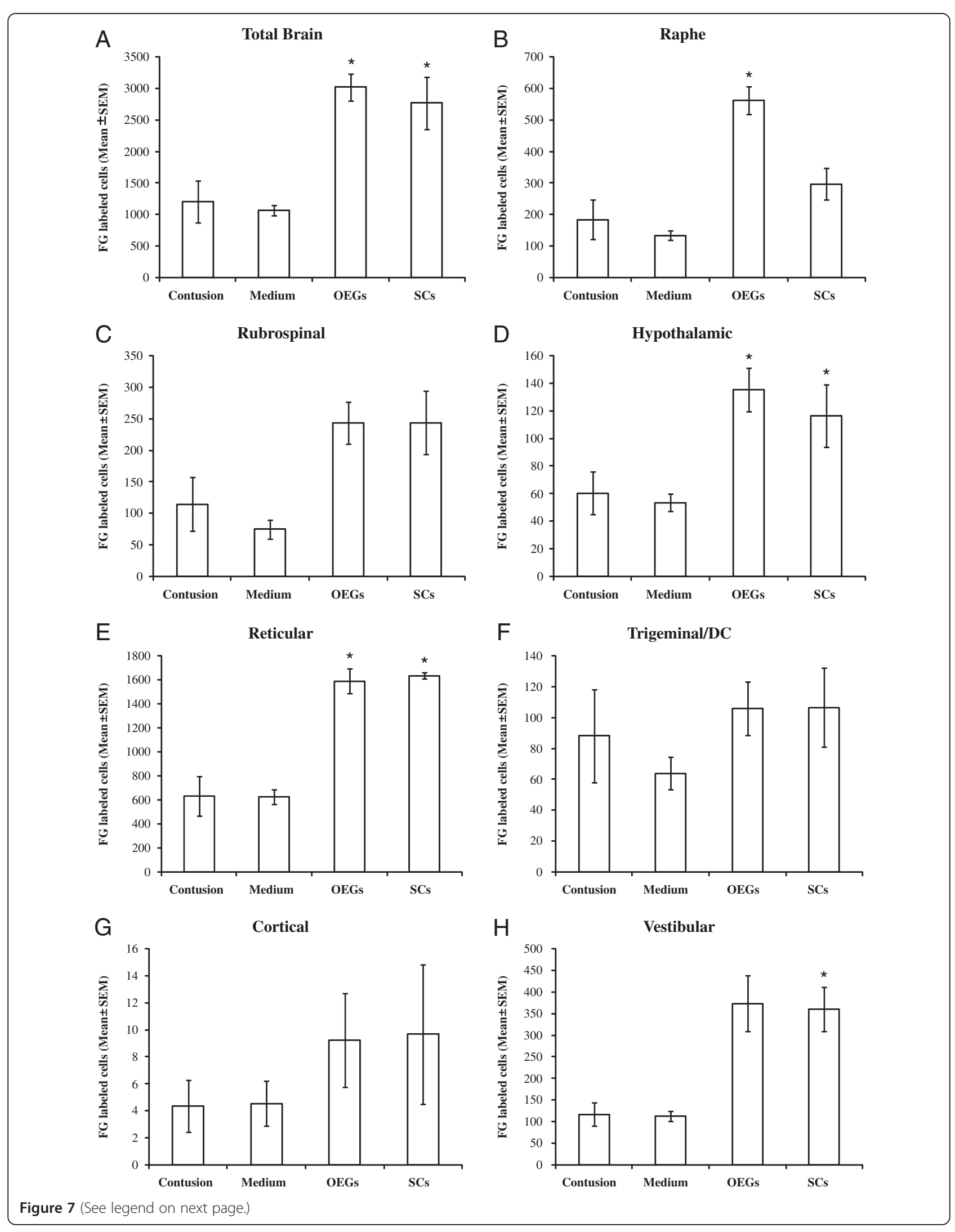


(See figure on previous page.)

Figure 7 Number of neurons in brain/brainstem nuclei retrogradely labeled with Fluorogold injected $8 \mathrm{~mm}$ caudal to the thoracic spinal cord lesion site. OEG transplantation into the contused spinal cord 14 days after injury promotes significant axonal sparing/regeneration of Raphe-, Vestibular- and Reticulo-spinal axons. Graphs depict the mean numbers of total FG-labeled neurons in the brains and brainstems of the four groups (A). Mean neuron numbers of the Raphe (B), Rubrospinal (C), Hypothalamic (D), Reticular (E), Trigeminal/DC (F), Cortical layer V (G) and Vestibular (H). Experimental groups were compared using a one-way analysis of variance (ANOVA), followed by the Dunnett's method of multiple comparisons versus a single control group (injury only) and also the Tukey test for multiple comparison procedures between all experimental and control groups.

post injury) these scores did not increase above control scores, with all groups scoring 10-11. At 2 weeks after treatment with cells or medium, control injury only rats scored a mean of 11, medium injected scored 10, OEG scored 12 and SCs scored 11 (Figure 9). Three weeks following injection of cells, the mean BBB scores for OEG injected rats were 13, SCs scored 12, medium injected scored 10 and injury only scored 11 . Theses scores were consistent for all the following time points until day 133 and 144 when OEG scored a mean of 14 , SCs scored 13, medium injected scored 11 and 10, and injury only scored 11 and 11 respectively (see Figure 9).
After one week of testing on the BBB score the rats were introduced to the ladder walk (see Figure 10A). At 6 weeks or 4 months after treatment, most rats scored between 3.5 and 5.5 (see Table 2) out of 6 on the horizontal ladder walking test (Figure 10B-C), with no significant differences observed between groups.

\section{Discussion}

We have shown the capacity of purified, primary OEG and SCs to promote behavioral recovery, increase numbers of supraspinal axons, and increase tissue sparing when transplanted two weeks after a moderate spinal

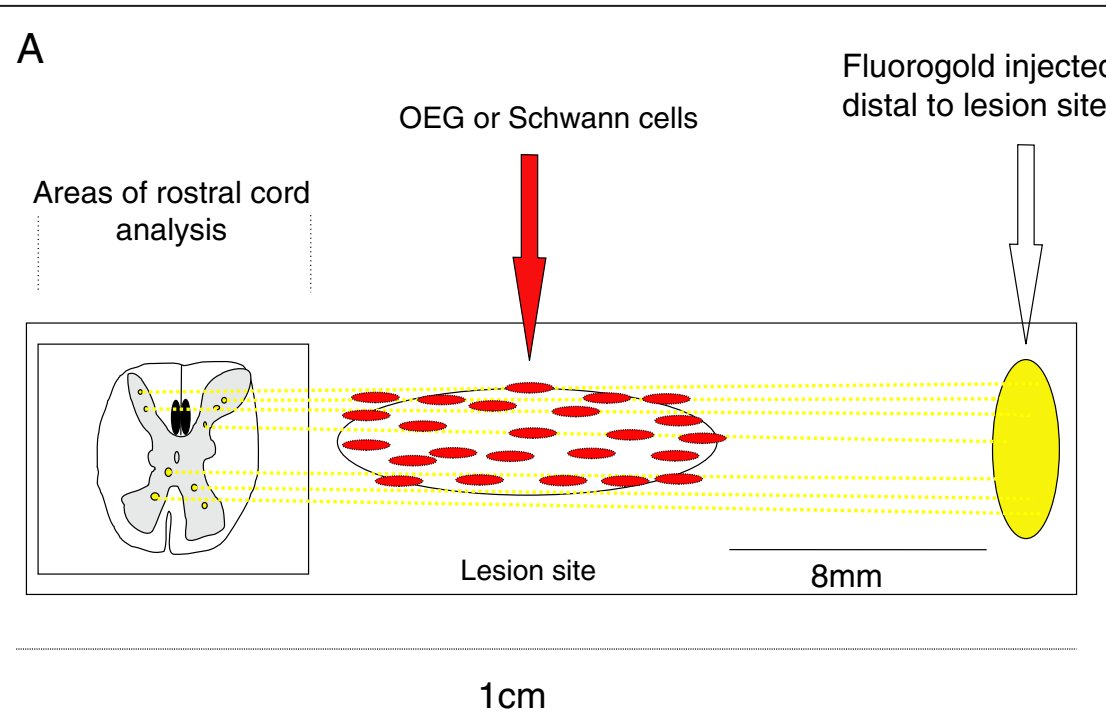

B

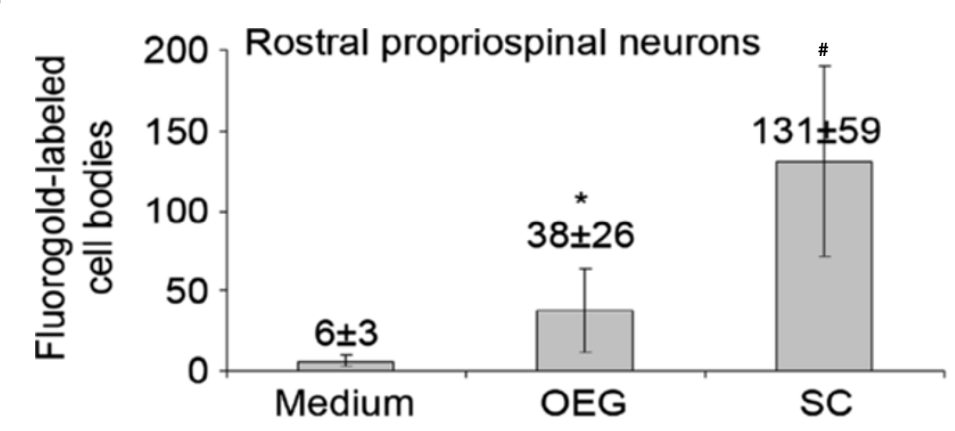

Figure 8 Propriospinal neurons rostral to the lesion site were retrogradely labeled with Fluorogold injected caudal $(8 \mathrm{~mm})$ to the lesion site (A). Significantly higher numbers of propriospinal neurons $(n=10, p<0.05)$ were observed in the Schwann cell-transplanted group (\#) and OEG-transplanted groups $\left(^{*}\right)$ relative to the medium-injected group (B). 


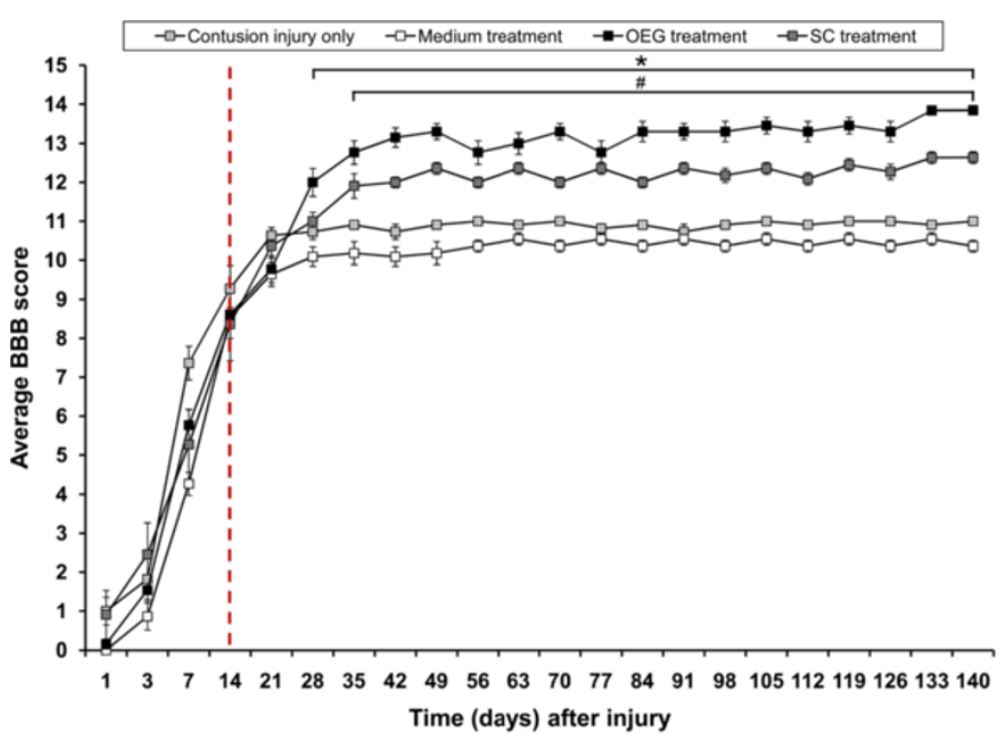

Figure 9 Mean BBB scores over 4 months after injection of medium, Schwann cells and OEG plotted against contusion injury only. The red dotted line depicts the transplant day. A statistically significant increase in BBB scores was seen in the Schwann cell group when compared to contusion only (\#, $\mathrm{p}<0.05)$. A significant increase in BBB scores was also seen in the OEG group when compared to control injury only $\left({ }^{*}, p<0.05\right)$.

cord contusion injury. A lentiviral vector encoding DSRED-2 was used to transduce OEG and SCs - in this study it was shown to be an effective and stable transgene to label both cell types up to 4 months in vivo following transplantation. Viable transplanted OEG and SCs were found in similar numbers at 2 weeks, but after 4 months the OEG numbers were less than the number of SCs remaining. Histochemical tissue analysis showed a significant reduction in tissue loss in both the OEG and SCs groups 4 months post-transplantation. Further, dorsal white matter tracts appeared to be better protected in the transplant groups than in non-cellular transplanted controls (medium). Analysis of DSRED-2 labeled glia in the spinal cords showed a migration/dispersal difference between the two cell types. OEG were more evenly distributed in a rostro-caudal direction, and greater integration of OEG with host astrocytes was evident when compared to the tight interwoven grafts in the SCs transplanted rats. OEG transplanted rats displayed significantly lower levels of CS56 immunofluorescence within and around the lesion/transplant site when compared to the SCs group. Matrix deposition was similar between OEG and SCs groups, but laminin and collagen IV immunofluorescence showed a closer co-existence of these matrix molecules to SCs than to OEG. Axonal staining using neurofilament antibodies showed tighter bundles of axons within the SCs transplant zone than in OEG zones. Open field behavioral testing (BBB) showed significant differences between the transplanted groups and the controls up to 4 months after transplantation. BBB scores were consistently higher in the OEG group compared to control injury, medium and SCs injected rats. Additional behavioral testing using the ladder walk however, did not show any significant differences between experimental and control groups. Fluorogold retrograde tracing $8 \mathrm{~mm}$ distal to the injury/transplantation site revealed significant differences between control groups and OEG and SCs transplanted groups in supraspinal projecting axon populations. This provides strong evidence that a sub-acute transplant of SCs or OEG provide an environment in which promotion of sparing/regeneration of supraspinal axonal projections to the spinal cord are increased.

\section{SCs and OEG differ in their interaction with host spinal cord cells and matrix production.}

Evidence of statistically significant tissue-protective effects of OEG was observed 4 months after transplantation. At 2 weeks post-transplantation, tissue loss was still occurring. The tissue-protective effects of transplanted OEG or SCs arise from the secretion of factors from the cells such as BDNF, NGF, GDNF and NT4/5 [13,46-48] or matrix (laminin-1, collagen IV) and adhesion molecule (N-Cadherin) secretion [49-51]. These mechanisms of protection combined with tissue-rebuilding or new cell birth [52], are potentially acting together to improve anatomical functional outcomes.

Proliferation of donor OEG seems unlikely, as the labeling method employed in this study would result in all daughter cells also being labeled; the number of labeled cells at 4 months in the lesion site were fewer than when counted at 2 weeks. The fewer numbers of detectable OEG involves movement away from the site of injury (measurement area), or death (via apoptotic or anoikis mechanisms) $[42,44]$. In a small number of 

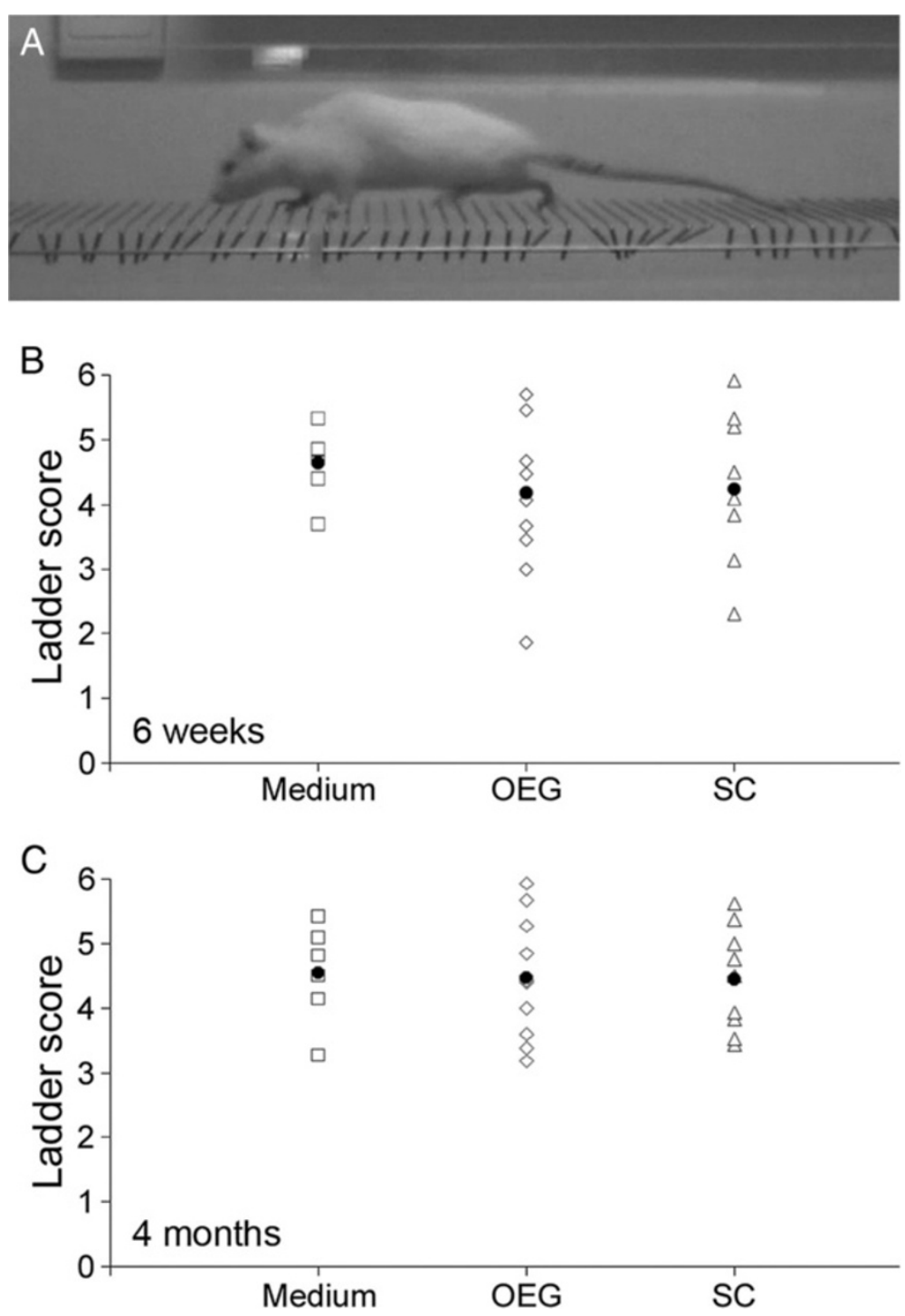

Figure $\mathbf{1 0}$ Ladder walking behavioral testing. A: representative photo of a rat traversing the horizontal ladder. B: ladder scores of treatment groups on horizontal ladder walking test 6 weeks after cell transplantation date. C: as for B at 4 months after cell transplantation date. At no stage were statistical differences between groups observed on the horizontal ladder test.

animals, OEG were observed several millimeters from the injection site which is similar to earlier studies which reported OEG migration at distances of $9 \mathrm{~mm}$ from the injection site $[9,53,54]$. In contrast to the OEG, SCs were not observed very far from the immediate lesion area, dispersing only up to a distance of $1.5 \mathrm{~mm}$. A similar lack of dispersal has been reported out of peripheral nerve grafts inserted into the adult CNS $[55,56]$. This is likely due to interactions with host astrocytes and other endogenous non-neuronal cells [57].

The observed difference in the amount of intact tissue between the OEG and SCs transplanted groups indicates chemotropic effects of the OEG [58], similar to the chemotropic effects exerted by glia during development
[59] that result in increased infiltration of various cells into the lesion site. OEG have the capacity to stimulate a different inflammatory response by the secretion of chemokines such as CX3CL1 [60], which is a known ligand for the receptor CX3CR1 found on microglia and dendritic cells $[60,61]$ and affects the amount of tissue preservation/removal. OEG potentially are be more susceptible to death and subsequent phagocytosis by macrophages than SCs. OEG are known to secrete different factors and have unique antigenic profiles other than the ones mentioned above which make them more susceptible to immune attack [62].

OEG and SCs transplants have the properties to directly influence proliferation or differentiation of spinal cord 


\begin{tabular}{ll} 
Table 2 Scoring scale developed for the ladder rung \\
walking test, modified from (Metz and Whishaw, [63]) \\
\hline Observation & Score \\
\hline Absent & 0 \\
Collapse & 0 \\
Deep slip then jump & 1 \\
Deep slip, unsuccessful or no paw replacement & 1 \\
Deep slip, paw replacement, slight slip & 2 \\
Step, unsuccessful paw replacement & 2 \\
Deep slip, successful paw replacement & 3 \\
Jump step & 3 \\
Step, paw replacement, slight slip & 4 \\
Step, good paw replacement & 4 \\
Slight slip, short stride & 5 \\
Slight slip, regular stride & 5 \\
Plantar paw placement, short stride & 6 \\
Plantar paw placement, regular stride & 6
\end{tabular}

progenitor cells/stem cells [52,63]. Glial transplants have the potential to differentiate these stem cells, like fibroblasts [64], into neurons or myelinating glia [64-67]. In our study we did not examine the direct OEG or SCs myelination potential or host myelination within the lesion site. Both cell types have the capacity to myelinate but differ in their effectiveness and mechanisms involved [75, Plant et al., -unpublished observations]. The proliferation of endogenous cells does occur in SCI [45]. These cells can include progenitor cells, endothelial and pericytes stimulated by factors such as epidermal growth factor and/or fibroblast growth factor-2 [68-70]. Proliferation seems highly plausible especially when OEG and SCs are known to produce similar levels of FGF-2 [71]. Two recent findings have indicated new cells play a role in SCI. New evidence from Goritz and colleagues [72] has indicated that pericytes play a role in the spinal cord injury response, whereby these cells actively migrate to sites of injury. OEG and SCs in our model are likely to have altered the number of these cells in the lesion site, thus providing a reparative outcome. In addition, evidence by Decimo and colleagues [73] found new adult stem cell /precursor cells that are resident in the meninges react to SCI and populate the injury site, thus providing a target for glial cell differentiation or activation.

In this study we provide evidence that following spinal cord contusion injury, endogenous repair processes including SCs migration were ongoing. Proliferation of ependymal cells in the walls of the central canal and from adjacent intact parts of spinal cord $[45,52,65,74,75]$ is one route. Ependymal cells are known to migrate and populate the lesion site along with new blood vessels, astrocytes and fibroblasts. This seems likely to have contributed to the cellular trabeculae and scar tissue seen within our lesion cysts $[45,75,76]$. Host SCs from the dorsal roots or blood vessels also infiltrated the lesion site in our model, based on large numbers of p75-positive/ DSRED-2 negative cells in all groups, as has previously been observed in the rat $[14,45,55,77,78]$ and human [79] with the majority from the dorsal roots [32].

In a previous study from our laboratory [57], we indicated that molecules (including neurotrophins) released by Schwann cells promote the reactivity of astrocytes. Transplanted SCs stimulate astrocytes to be highly GFAP positive and surrounded by CS56 staining. This forms a dense glial scar around the lesion and prevents the entry of axons, and/or other host non-neuronal cells [57]. In this study we demonstrate in sub-acute 14 day glial transplants, OEG were associated with significantly lower CS56 expression and slightly higher collagen IV expression in the lesion and graft site compared to SCs. Since OEG are proficient in interacting with astrocytes in vitro [49,80], their release of extracellular matrix and cell adhesion molecules and their modulation of these factors may also account for the observed axonal infiltration into the glial scar [81]. Molecules such as Fibulin-3 and its ability to bind TIMP-3 may also play a part in the different interaction with host glia [26]. OEG isolated from the olfactory bulb show high levels of this protein when compared to SCs [26]. One recent report has also suggested an important role of MMP's in cell migration and modulation of the ECM [82]. While both OEG and SCs appeared to be associated with a greater quantity of extracellular matrix molecules in the lesion site compared to the effect of medium injection alone, their profiles differed. The laminin was present in a complementary and nonoverlapping pattern to DSRED-2 labeled SCs and OEG. SCs appeared to produce basement membrane, while OEG are capable of producing these molecules but not in the quantity seen in SCs grafted animals; rather, they may have induced other cells to produce extracellular matrix such as astrocytes or endothelial cells. This is not surprising given the role the OEG play in the olfactory system, where OEG form channels which stay present even after axonal degeneration in the olfactory bulb for axons to grow through and out to innervate areas of the olfactory bulb $[83,84]$. One mechanism for OEG reparative outcomes in the CNS is their close "crosstalking" with fibroblasts/meningeal cells [see 48,81] and ability to interact with these cells $[9,85]$. OEGs have a very close relationship with fibroblasts in the olfactory system, as do SCs in the peripheral nerve, but their role seems very different. SCs are potentiated to myelinate axons by fibroblasts and their associated matrix [86], whereas OEG interact in an axonal replacement/regenerating system without myelination [87]. In addition they have previously been shown 
play a role in fascicle-forming arrangements without fibroblasts [88-90].

\section{Olfactory glia and Schwann cells increase axonal sparing/ regeneration in sub acute treated $\mathrm{SCl}$}

Our results show that transplantation of OEG or SCs at 2 weeks after contusion facilitated significant axonal sparing/regeneration comparable to those seen in transplants carried out 7 days after a contusion injury [33]. Significant increases in regenerated propriospinal fibers were also present in both graft groups, but numbers in SCs treated animals were significantly higher than after OEG transplantation. This indicates a more potent, local secretion of factors by SCs compared to OEG, but as yet no study has extensively analyzed these differences. In this study, an OEG or SCs transplantation following a contusion injury was associated with an increased amount of intact tissue at the lesion site. Immunohistochemistry for neurofilament-positive axons showed strongly immunoreactive profiles at the lesion site for both OEG and SCs transplanted groups after a 14 day delay of transplantation. Neurofilament positive axons in the SCs group were less linearly organized than those seen in the OEG group. This could be explained by the interaction with host astrocytes not allowing for the even distribution of the cells and the formation of a clear cellular boundary [91].

Retrograde tracing using Fluorogold revealed statistically significant increased numbers for supraspinal tracts after OEG or SCs transplantation. Supraspinal spinal tracts such as reticular, vestibular and hypothalamic were seen to respond similarly in both transplant groups. It should be noted that these supraspinal fibers were measured from $8 \mathrm{~mm}$ distal to the injury site, and so possible differences in fiber numbers between the transplanted cell groups at the lesion site itself cannot be discounted. Unlike the other spinal tracts, the raphe tract responded in a far more robust fashion in the OEG group. This can be via increased responsiveness to BDNF from the OEG directly or by the interaction with activated microglia which are known to secrete BDNF after ATP activation through the P2X4 receptor [92]. OEG differ to SCs in their levels of fractalkine secretion, and this can activate microglia to become more active and secrete different neurotrophic profiles to that initiated by SCs that do not secrete this protein at the same level. An important consideration, that is difficult to assess at the time of cell delivery, is the stage of cellular differentiation of transplanted glia after a period of time in vivo. SCs will differentiate into myelin forming cells quite quickly thus reducing their regenerative/autocrine secretory products [93-95] whereas OEG stay in an undifferentiated [p75-positive) non-myelin forming state for a longer periods (Plant - unpublished observations) or may not myelinate at all [33].

\section{Functional recovery is improved after sub acute transplantation of OEG and SCs}

Significant behavioral differences were observed between the control injury and medium injected rats, and both OEG and SCs grafted groups. Improvements, which are normally observed in studies similar to that undertaken here, may result from compensatory effects occurring within reflex-based segmental cord systems [96]. OEG transplantation into a completely transected spinal cord has elicited improved hindlimb function $[9,10,97]$ as seen here. One possibility that could increase locomotion is increased noradrenergic and serotonergic varicosities apposing the motor associated cholinergic neurons [98]. OEG treated rats showed significant numbers of raphe projecting axons reaching at least $8 \mathrm{~mm}$ distal from the injury site and these could stimulate such a behavioral response. This however does not explain the SCs grafted rats which may use an alternate but effective pathway of locomotion. SCs induced recovery could be partially explained by a graft relay system developed through regeneration of propriospinal axons regeneration as seen in our results here. Only small numbers of spared fibers $(<5 \%)$ are required to facilitate compensatory return of function via segmental circuits [99]. Phasic behavioral recovery in the SCs group, in particular 49 days until the end of the experiment, may be due to phasic secretion of neurotrophins which may not be delivered at the same level via the transplantation of OEG.

\section{Conclusions}

Glial cells transplanted at 14 days post injury may experience a less accommodating lesion site than when grafted 1 week after injury, which may explain a reduced glial survival in particular for OEG than seen in earlier transplant studies. At 14 days post SCI proteoglycan deposition at the lesion site is present and highly inhibitory [100,101] but was shown to be reduced in the OEG transplanted groups providing a positive milieu for the sparing/regeneration of supraspinal axons (serotonergic positive fibers). This evidence is strongly backed by our use of fluorogold tracing, but was not supported by immunohistochemistry for 5-HT [98] (which labels serotonergic axons innervating the spinal cord). Supplementation of glial transplants with neurotrophins may improve cell survivability [13] and in combination with removal of the glial scar by the use of chondroitinase could potentially improve axonal regeneration in this 14 day delayed glial transplant model $[102,103]$. Clearly the delay between injury and treatment can have a strong bearing on the experimental outcome but also the success of the glial type to improve tissue and behavioral outcomes, modify the lesion site and improve sparing/regeneration of axonal populations as shown here. From the present study it would appear that a 14 day delay in glial transplantation is feasible and beneficial both 
anatomically and behaviorally after a contusive spinal cord injury but the mechanisms of repair of the two glial types are different. We have examined two time points (2 weeks and 4 months) using multiple behavioral and anatomical analysis, but results can only give an indication of efficacy. Further physiological, behavioral and anatomical correlative studies using these glial cells at 14 days post injury time point would provide valuable evidence of cell potential and reproducibility for future CNS repair applications.

\section{Methods}

\section{Animals}

Adult (180-200 g) female Fischer 344 rats (Animal Resource Centre, Murdoch, Western Australia) were housed in groups of three under controlled conditions of temperature and humidity, with free access to food and water. All procedures were approved by the Animal Ethics Committee of The University of Western Australia (approval number 99/008/E42). Fourteen days after injury, previously described injection procedures [8] were used to transplant OEG ( $\mathrm{n}=6$ short term 2 weeks, and $n=11$ long term 4 months) or SCs $(n=6$ short term 2 weeks and $n=11$ long term 4 months) into the lesion site controls received an injection of cell culture medium ( $\mathrm{n}=6$ short term 2 weeks and $n=11$ long term 4 months) or injury alone ( $\mathrm{n}=6$ short term 2 weeks and $\mathrm{n}=11$ long term 4 months). Six additional rats were perfused 2 weeks after contusion without a transplant, to examine the lesion milieu into which transplanted cells would have been introduced. Total rats used $n=74$. All rats receiving a transplant and/or medium were perfused at 2 weeks or 4 months after transplantation. The numbers of animals were final numbers analyzed. In the long term groups 3 animals died and in the short term groups 6 rats.

\section{Olfactory ensheathing glia and Schwann cell culture and purification}

OEG were prepared from the olfactory bulbs of adult female Fischer 344 rats $[8,13,33]$. In brief, the bulbs were extirpated and the olfactory nerve layer dissected. Tissue was mechanically dissociated and treated with trypsin $0.5 \% \mathrm{w} / \mathrm{v}$ (Worthington Biochemical Corporation, Lakewood, NJ) in Hank's Balanced Saline Solution (Sigma) for 60 minutes at $37^{\circ} \mathrm{C}$ in a $\mathrm{CO}_{2}$-free incubator. Tissue was pelleted by centrifugation at $1500 \mathrm{rpm}$ for 5 minutes, resuspended in DF10S medium (1:1 DMEM/ F-12 -Sigma), 10\% (v/v) fetal calf serum - Hunter Antisera) supplemented with bovine pituitary extract $(20 \mu \mathrm{g} / \mathrm{mL}$ Gibco) and forskolin ( $2 \mu \mathrm{M}$ Sigma), then plated on polyL-lysine-coated culture dishes (Corning, Acton, MA) for one week. OEG were purified by immunoaffinity to an antibody to the p75 receptor (192-IgG) [13,33].

SCs were isolated from adult female Fischer 344 rats $[19,33]$. Briefly, the sciatic nerves were dissected, placed in $35 \mathrm{~mm}$ uncoated tissue culture dishes in D10S medium consisting of DMEM (Sigma St Louis, MO) with 10\% fetal calf serum (Hunter Antisera Jesmond, NSW, Australia) and cut into 1-2 $\mathrm{mm}^{3}$ pieces. Each week, nerve segments were transferred to a new culture dish, leaving behind fibroblasts that had migrated out of the explants. After three weeks of fibroblast depletion, explants were enzymatically and mechanically dissociated and transferred to new dishes for culture in the presence of bovine pituitary extract $(20 \mu \mathrm{g} / \mathrm{mL}$ Gibco, Carlsbad, CA) and forskolin (2 $\mu$ M Sigma) [22].

\section{Lentiviral labelling of glia}

Lentiviral vectors encoding the gene for DSRED-2 were made according to methods described by [104]. Cultured OEG or SCs were labeled by adding the vector (using a multiplicity of infection of 100 [12] to the culture medium for 16 hours, followed by 2 washes in culture medium and fresh media for growth.

\section{Spinal cord injury and post-operative care}

Anesthesia was induced with $5 \%(\mathrm{v} / \mathrm{v})$ halothane (in $60: 40 \mathrm{O}_{2}: \mathrm{N}_{2} \mathrm{O}$ ) then maintained at 2-3\%. The skin and muscle layers were cut rostro-caudally to expose the vertebral column, and a T10 laminectomy performed [8] Using an New York University (NYU) impactor, a moderate contusion injury was induced by dropping a $10 \mathrm{~g}$ weight from a $12.5 \mathrm{~mm}$ height $[99,105]$ Gel-Foam (Pharmacia \& Upjohn, Kalamazoo, MI) was used to stop bleeding in some animals. Animals were partially suspended from clamps to the dorsal processes of T8 and T11/12, to circumvent diaphragm-induced dorso-ventral movement of the spinal column. Immediately after the injury, the animal was removed from the clamps and the muscles sutured in layers with Vicryl (Johnson \& Johnson, New Brunswick, NJ). Skin was closed with Michel suture clips (Fine Science Tools Inc., North Vancouver, BC, Canada). Immediately after surgery, each animal was injected with penicillin (Benacillin intramuscular), analgesic (Temgesic buprenorphine sub-cutaneous $0.1 \mathrm{mg} / \mathrm{kg}$ ) and $2-4 \mathrm{~mL}$ $0.9 \%$ saline (sub-cutaneous). Animal cages were placed partially onto a heating pad for 24 hours, to assist with maintenance of body temperature. Antibiotics were continued on alternate days, with analgesic twice daily and saline once daily for one week. Manual bladder expression was performed twice daily for two to three weeks, by which time all animals had recovered bladder tone.

\section{Cell transplantation}

Cells were transplanted after no more than 2 weeks in vitro [8]. Fourteen days post-contusion, adult female rats were anesthetized and the spinal cord exposed as described above. Either $5 \mu \mathrm{L}$ of a cell suspension containing $5 \times 10^{5}$ OEG or SCs in culture medium, or medium alone, 
(1:1 DMEM/F-12 Sigma) was injected into the center of the lesion over a period of 3 minutes using a $5 \mu \mathrm{L}$ syringe (Hamilton, Reno, NV) mounted in a stereotaxic frame. The needle was withdrawn 3 minutes later to encourage cell integration into the injection site. Wounds were sutured and post-operative care was administered as described above.

\section{Behavioral testing}

All testing of the $\mathrm{BBB}$ and ladder walk were carried out by observers blinded to the treatments. BBB testing [99] was performed on each animal on the day following contusion, to confirm the successful lesion (a score of 0). The BBB test was repeated on day 3 , day 7 and day 14 after contusion thereafter every week after cell transplantation. 3 weeks post-injury, animals were consistently scoring $\mathrm{BBB}$ results of 10-11. A ladder rung walking test modified from [106] was introduced 1 week after injury and measured every week for 4 months. The ladder rung walking test provided 6 points (Table 2) for scoring, thus allowing a greater level of sensitivity than the two BBB points by which they were separated.

The ladder rung walking test [106] apparatus was $1.5 \mathrm{~m}$ in length and consisted of two clear Perspex sidewalls and a floor with removable metal rungs spaced $1 \mathrm{~cm}$ apart. Prior to surgery, rats were trained to walk along the ladder to reach their home cage. From 1 week after injury, trials were performed weekly and video recorded. The animals had 3 runs per day when tested. The video camera was positioned to capture the central portion of the ladder, approximately $30 \mathrm{~cm}$ in length, allowing analysis of approximately 8 steps of each hind limb. Each hind limb step in each trial was later scored (Table 2) the scores were averaged to give a single value, per rat, per trial.

\section{Fluorogold labeling}

Ten days prior to perfusion (4 months post-transplantation of cells), 11 rats from each of the long term (4 month) groups were anesthetized as above and subjected to a T12 laminectomy. While held in a stereotaxic frame, Fluorogold (1 $\mu \mathrm{L}$ Fluorochrome Inc., Denver, CO) was injected into the spinal cord at 4 points $(0.25 \mu \mathrm{L}$ each), 2 segments caudal $(8 \mathrm{~mm})$ to the contusion site. All injections were performed by the same individual, to maximize comparability between animals this individual was also blinded as to which groups had previously been injected with OEG, SCs or control cells. Muscles were sutured in layers and the skin closed with Michel suture clips (Fine Science Tools Inc., North Vancouver, BC, Canada). Animals were treated with the post-operative care regime detailed above.

\section{Tissue processing}

At 2 weeks or 4 months after Schwann cell or OEG transplantation, rats were terminally anesthetized with
Nembutal (intraperitoneal sodium pentobarbital Merial Australia, Parramatta, NSW, Australia) and perfused intracardially with approximately $150 \mathrm{~mL}$ of heparinized phosphate-buffered saline (Heparin $1 \mathrm{U} / \mathrm{mL}$ David Bull Laboratories, Melbourne, VIC, Australia) followed by approximately $150 \mathrm{~mL}$ 4\% buffered paraformaldehyde solution. The spinal cord and brain were immediately removed and post-fixed in buffered paraformaldehyde overnight at $4^{\circ} \mathrm{C}$. The following day, paraformaldehyde was replaced with $0.1 \mathrm{M}$ phosphate buffer. Prior to tissue sectioning, each spinal cord or brain was placed into sucrose $(30 \% \mathrm{w} / \mathrm{v}$ in phosphate buffer) overnight and embedded in gelatin $(10 \% \mathrm{w} / \mathrm{v}$ in phosphate buffer Difco, Franklin Lakes, NJ). The gelatin block was fixed by immersion in buffered paraformaldehyde for 2 hours and placed into buffered sucrose solution overnight. Tissue was sectioned (spinal cord at $40 \mu \mathrm{m}$ brain at $50 \mu \mathrm{m})$ using a freezing sledge microtome and placed into phosphate buffer containing $0.05 \% \mathrm{w} / \mathrm{v}$ sodium azide.

\section{Tissue analysis - Quantification}

Numbers of animals per group were 8-12 and based on: (i) a prior power analysis study to ascertain experimental numbers in animal models of spinal cord injuries, in order to appropriately assess statistical differences, and (ii) previous publications from the laboratory. All rats were tested with BBB, gridwalk, fluorogold traced, immunohistochemistry, and tissue analysis. These were randomly allocated to the groups without the knowledge of the surgeon or behaviorist. Animals were taken from the naïe cages and re-housed into post-surgery cages and numbered. This number was then combined by an independent person to identify the treatment. At every level the person was blinded to the treatment.

The perfusions were performed on the same day for all groups with the same fixative batch. The immunohistochemistry was also carried out between each of the groups reducing differences in staining between days and groups. The analysis was performed by a trained viewer who was blinded to the groups.

\section{Tissue volume estimation}

One in six sections from each spinal cord was mounted onto gelatin-coated microscope slides and stained with gold chloride solution for myelin followed by cresyl violet for Nissl substance [107]. Slides were dehydrated through an ethanol/toluene series and mounted in DPX (Chem Supply, Gillman, Australia). Sections were visualized using a Leica DM RBE microscope and digitally photographed. Image Pro Plus (Media Cybernetics, Silver Spring, MD) was used to measure the tissue area of a $4.5 \mathrm{~mm}$ section of spinal cord with the lesion center at its midpoint.

Tissue cavitation was measured in all animals to gain an estimate of the effect of the transplanted cells upon 
the preservation of tissue at the lesion site the volume of tissue remaining at the injury site was measured in a similar manner to that described previously $[8,14,108]$ The combined area of any cysts was calculated and subtracted from the total tissue area of the section, to give a value for the total tissue remaining. Areas showing signs of degeneration, such as microcysts and loss of neuronal profiles, were subtracted from the values for total tissue remaining to obtain a measure of intact tissue. The values for the centre four sections of each spinal cord were averaged to give a single semi-quantitative value of remaining tissue volume value for each rat. Values from four equivalent sections of an uninjured spinal cord were used to compute the tissue remaining as a proportion of uninjured spinal cord.

\section{Immunohistochemistry}

Series of one in six tissue sections (in 2 week or 4 month time points) were immunostained free-floating with mouse monoclonal or rabbit polyclonal antibodies. Sections were incubated overnight at $4^{\circ} \mathrm{C}$ in primary antibody diluted in phosphate buffer containing 10\% normal goat serum and $0.2 \%$ (v/v) Triton X-100. Mouse monoclonal antibodies used were: i) anti-chondroitin sulfate proteoglycans (CS-56 1:50 Sigma) to identify proteoglycan deposition at the lesion site, ii) low affinity nerve growth factor receptor p75 (supernatant 192-IgG) to stain for OEG and Schwann cells (both transplanted and endogenous) and iii) anti medium/ high neurofilaments RT-97 (supernatant Developmental Hybridoma Bank) to stain for spared and regenerated axons. Rabbit polyclonal antibodies were used for: i) p75 (1:200 Promega, Madison, WI), Glial fibrillary acidic protein (GFAP) (1:500 DakoCytomation, Denmark) to stain for astrocytes, unmyelinated Schwann cells and olfactory glia, ii) anti-collagen IV (1:200 Rockland Inc., Gilbertsville, PA) to ascertain the distribution of basal lamina and blood vessels and iii) anti-laminin-1 (1:200 Sigma) for basal lamina and blood vessels.

The following day, sections were washed three times with phosphate buffer and incubated with secondary antibody (diluted in the same solution as for primary antibodies) for 30 minutes at room temperature. Sections were washed three times with phosphate buffer, mounted onto gelatin-coated glass microscope slides, air dried and then coverslipped in a glycerol-based mounting medium.

\section{Semi-quantitative analysis of proteoglycan, matrix and cell survival in vivo}

One in 6 series of sections at 4 months post transplantation (and controls) were analyzed. Low magnification photomicrographs $(10 \times$ objective) were taken using an IX70 Olympus microscope. Pixel fluorescence of immunostaining for CS-56, laminin and collagen IV was measured at rostral, middle and caudal locations of the contusion/ injury sites and the average pixel fluorescence minus background readings of the three areas compared between medium control and OEG or SCs groups [37,57]. In addition, one in 4 series of sections were analyzed for the presence of DSRED-2 labeled cells in the 2 week and 4 month survival groups. Pixel fluorescence was then compared between the 2 survival points to estimate survival of OEG and SCs at 4 months expressed as a percentage of those present at 2 weeks.

\section{Fluorogold photography and counts}

A 1 in 6 series of brain sections were mounted onto gelatin-coated glass microscope slides, air-dried and mounted in a glycerol-based mounting medium. Sections were photographed with a Hitachi HV-C20M digital camera as a large tiled image using a fluorescence microscope (Leica DM RBE) with a motorized stage controlled with Image Pro Plus (5.1) software (Media Cybernetics). The optical dissector method was used to photograph and count fluorogold-labeled neurons, in order to avoid inaccuracies due to double counting [109] Photographs were taken in the centre of the $\mathrm{z}$-axis of each section. Those cell bodies in focus were identified, then tagged and counted using Image Pro Plus. Seven areas were analyzed: the reticular formation, vestibular nucleus, trigeminal and dorsal column nuclei, raphe nucleus, red nucleus, hypothalamus and motor cortex.

To quantify sparing/regeneration of descending propriospinal neurons, the labeled cell bodies were counted using an identical method in the spinal cord region rostral to the lesion site. Six spinal cord sections (1 cm in length) from each animal were analyzed.

\section{Statistical analysis}

The methods of statistical analysis were chosen that reflected the animal numbers used in this study. For Fluorogold labeling of supraspinal projecting nuclei in the brain, experimental groups were compared using a one-way analysis of variance (ANOVA) followed by the Dunnetts methods of multiple comparisons versus a single control group (injury only) and also the Tukey test for multiple comparison procedures between all experimental and control groups. Fluorogold analysis of propriospinal projections into the distal spinal cord were analyzed using a one way analysis of variance (ANOVA). This was also the case for the tissue sparing and proteoglycan and cell survival analysis. In the analysis of the BBB scores, groups were compared using the non parametric Kruskal Wallace ANOVA on ranks. This was followed by Dunnetts method of multiple comparisons versus a single control group. 


\section{Additional file}

Additional file 1: Table S1. DSRED-2 Fluorescence Counts in OEG Transplanted and SC Transplanted groups.

\section{Abbreviations}

OEG: Olfactory ensheathing glia; SCs: Schwann cells; BBB: Basso, Beattie and Bresnahan; ANOVA: One way analysis of variance; SCl: Spinal cord injury; GFP: Green fluorescent protein; GFAP: Glial fibrillary acidic protein; BDNF: Brain derived neurotrophic factor; NGF: Nerve growth factor; GDNF: Glial derived neurotrophic factor; NT4/5: Neurotrophin 4/5; DMEM: Dulbecco's modified eagle's medium; NYU: New York University.

\section{Competing interests}

The authors declare that they have no competing interests.

\section{Authors' contributions}

$\mathrm{HB}$ contributed to the acquisition of data, analysis and interpretation. CDP contributed to the analysis of data, drafting of manuscript and revising for intellectual content. ARH contributed to the analysis of data, drafting of manuscript and intellectual content. GWP conceived of the study and design, acquisition of data, analysis and drafted the manuscript. All authors have read and approved the manuscript.

\section{Acknowledgements}

We wish to express thanks to Seok Voon Lee for technical contributions. We sincerely thank William Hendriks and Joost Verhaagen for their help with lentiviral vector design and production. GWP's laboratory was supported by the National Health and Medical Research Council (RD Wright Fellowship No. 303265), Eileen Bond, Australian Rotary Health Research Fund, Spinal Cure Australia. Stanford University, James Doty Neurosurgery Fund, and Hearst Neuroscience Fund.

\section{Author details}

${ }^{1}$ Department of Neurosurgery, Stanford Partnership for Spinal Cord Injury and Repair, Stanford University, Lorry I Lokey Stem Cell Research Building, 265 Campus Drive, Stanford, CA 94305, USA. ${ }^{2}$ Eileen Bond Spinal Research Center, University of Western Australia, Perth, Australia. ${ }^{3}$ School of Anatomy Physiology and Human Biology, University of Western Australia, Perth, Australia.

\section{Received: 19 February 2013 Accepted: 18 September 2013}

Published: 27 September 2013

\section{References}

1. Doucette R: PNS-CNS transitional zone of the first cranial nerve. J Comp Neurol 1991, 312(3):451-466.

2. Ramer LM, Richter MW, Roskams AJ, Tetzlaff W, Ramer MS: Peripherallyderived olfactory ensheathing cells do not promote primary afferent regeneration following dorsal root injury. Glia 2004, 47(2):189-206.

3. Richter MW, Roskams AJ: Olfactory ensheathing cell transplantation following spinal cord injury: Hype or hope? Exp Neurol 2008, 209(2):353-367.

4. Ruitenberg MJ, Vukovic J, Sarich J, Busfield SJ, Plant GW: Olfactory ensheathing cells: characteristics genetic engineering and therapeutic potential. J Neurotrauma 2006, 23(3-4):468-478.

5. Graziadei PP, Monti Graziadei GA: Neurogenesis and neuron regeneration in the olfactory system of mammals III. Deafferentation and reinnervation of the olfactory bulb following section of the fila olfactoria in rat. J Neurocytol 1980, 9(2):145-162.

6. Monti Graziadei GA, Karlan MS, Bernstein JJ, Graziadei PP: Reinnervation of the olfactory bulb after section of the olfactory nerve in monkey (Saimiri sciureus). Brain Res 1980, 189(2):343-354.

7. Li Y, Field PM, Raisman G: Repair of adult rat corticospinal tract by transplants of olfactory ensheathing cells. Science 1997, 277(5334):2000-2002.

8. Plant GW, Christensen CL, Oudega M, Bunge MB: Delayed transplantation of olfactory ensheathing glia promotes sparing/regeneration of supraspinal axons in the contused adult rat spinal cord. J Neurotrauma 2003, 20(1):1-16.
9. Ramon-Cueto A, Plant GW, Avila J, Bunge MB: Long-distance axonal regeneration in the transected adult rat spinal cord is promoted by olfactory ensheathing glia transplants. J Neurosci 1998, 18(10):3803-3815.

10. Ramon-Cueto A, Cordero Ml, Santos-Benito FF, Avila J: Functional recovery of paraplegic rats and motor axon regeneration in their spinal cords by olfactory ensheathing glia. Neuron 2000, 25(2):425-435.

11. Ruitenberg MJ, Levison DB, Lee SV, Verhaagen J, Harvey AR, Plant GW: NT-3 expression from engineered olfactory ensheathing glia promotes spinal sparing and regeneration. Brain 2005, 128(Pt 4):839-853.

12. Ruitenberg MJ, Plant GW, Christensen CL, Blits B, Niclou SP, Harvey AR, Boer $G J$, Verhaagen J: Viral vector-mediated gene expression in olfactory ensheathing glia implants in the lesioned rat spinal cord. Gene Ther 2002, 9(2):135-146.

13. Ruitenberg MJ, Plant GW, Hamers FP, Wortel J, Blits B, Dijkhuizen PA, Gispen WH, Boer GJ, Verhaagen J: Ex vivo adenoviral vector-mediated neurotrophin gene transfer to olfactory ensheathing glia: effects on rubrospinal tract regeneration lesion size and functional recovery after implantation in the injured rat spinal cord. J Neurosci 2003, 23(18):7045-7058.

14. Takami T, Oudega M, Bates ML, Wood PM, Kleitman N, Bunge MB: Schwann cell but not olfactory ensheathing glia transplants improve hindlimb locomotor performance in the moderately contused adult rat thoracic spinal cord. J Neurosci 2002, 22(15):6670-6681.

15. Guest JD, Rao A, Olson L, Bunge MB, Bunge RP: The ability of human Schwann cell grafts to promote regeneration in the transected nude rat spinal cord. Exp Neurol 1997, 148(2):502-522.

16. Imaizumi T, Lankford KL, Burton WV, Fodor WL, Kocsis JD: Xenotransplantation of transgenic pig olfactory ensheathing cells promotes axonal regeneration in rat spinal cord. Nature Biotech 2000, 18(9):949-953.

17. Xu XM, Chen A, Guenard V, Kleitman N, Bunge MB: Bridging Schwann cel transplants promote axonal regeneration from both the rostral and caudal stumps of transected adult rat spinal cord. J Neurocytol 1997 26(1):1-16.

18. Xu XM, Guenard V, Kleitman N, Bunge MB: Axonal regeneration into Schwann cell-seeded guidance channels grafted into transected adult rat spinal cord. J Comp Neurol 1995, 351(1):145-160.

19. Morrissey TK, Kleitman N, Bunge RP: Isolation and functional characterization of Schwann cells derived from adult peripheral nerve. J Neurosci 1991, 11(8):2433-2442.

20. Pearse DD, Barakat DJ: Cellular repair strategies for spinal cord injury. Expert Op Biol Ther 2006, 6(7):639-652

21. Pearse DD, Sanchez AR, Pereira FC, Andrade CM, Puzis R, Pressman $Y$, Golden K, Kitay BM, Blits B, Wood PM, Bunge MB: Transplantation of Schwann cells and/or olfactory ensheathing glia into the contused spinal cord: Survival migration axon association and functional recovery. Glia 2007, 55(9):976-1000.

22. Plant GW Ramon-Cueto A, Bunge MB: Transplantation of Schwann cell of Schwann cells and ensheathing glia to improve regeneration in adult spinal cord. In Axonal Regeneration in the Central Nervous System. Edited by Ingoglia N, Murray M. New York and Basel: Marcel Dekker Inc; 2001a:529-561.

23. Harvey AR, Plant GW: Olfactory ensheathing glia and spinal cord injury: basic mechanisms to transplantation. Fut Neurol 2006, 1(4):453-463.

24. van den Pol AN, Santarelli JG: Olfactory ensheathing cells: time lapse imaging of cellular interactions axonal support rapid morphologic shifts and mitosis. J Comp Neurol 2003, 458(2):175-194.

25. Vincent AJ, West AK, Chuah MI: Morphological plasticity of olfactory ensheathing cells is regulated by CAMP and endothelin-1. Glia 2003, 41(4):393-403.

26. Vukovic J, Ruitenberg MJ, Roet K, Franssen E, Arulpragasam A, Sasaki T, Verhaagen J, Harvey AR, Busfield SJ, Plant GW: The glycoprotein fibulin-3 regulates morphology and motility of olfactory ensheathing cells in vitro. Glia 2009, 57(4):424-443.

27. Ramon-Cueto A, Perez J, Nieto-Sampedro M: In vitro enfolding of olfactory neurites by $\mathrm{p} 75$ NGF receptor positive ensheathing cells from adult rat olfactory bulb. Eur J Neurosci 1993, 5(9):1172-1180.

28. Lu J, Feron F, Ho SM, Mackay-Sim A, Waite PM: Transplantation of nasal olfactory tissue promotes partial recovery in paraplegic adult rats. Brain Res 2001, 889(1-2):344-357.

29. Lu P, Yang H, Culbertson M, Graham L, Roskams J, Tuszynski MH: Olfactory Ensheathing Cells Do Not Exhibit Unique Migratory or Axonal Growth- 
Promoting Properties after Spinal Cord Injury. J Neurosci 2006, 26:11120-11130.

30. Richter MW, Fletcher PA, Liu J, Tetzlaff W, Roskams AJ: Lamina propria and olfactory bulb ensheathing cells exhibit differential integration and migration and promote differential axon sprouting in the lesioned spinal cord. J Neurosci 2005, 25(46):10700-10711.

31. Boyd JG, Lee J, Skihar V, Doucette R, Kawaja MD: LacZ-expressing olfactory ensheathing cells do not associate with myelinated axons after implantation into the compressed spinal cord. Proc Natl Acad Sci U S A 2004, 101(7):2162-2166.

32. Nagoshi N, Shibata S, Hamanoue M, Mabuchi Y, Matsuzaki Y, Toyama Y, Nakamura M, Okano H: Schwann cell plasticity after spinal cord injury shown by neural crest lineage tracing. Glia 2011, 59(5):771-784.

33. Plant GW, Currier PF, Cuervo EP, Bates ML, Pressman Y, Bunge MB, Wood PM: Purified adult ensheathing glia fail to myelinate axons under culture conditions that enable Schwann cells to form myelin. J Neurosci 2002, 22(14):6083-6091.

34. DiStefano PS, Johnson EM Jr: Identification of a truncated form of the nerve growth factor receptor. Proc Natl Acad Sci U S A 1988, 85(1):270-274.

35. Zupan AA, Johnson EM Jr: Evidence for endocytosis-dependent proteolysis in the generation of soluble truncated nerve growth factor receptors by A875 human melanoma cells. J Biol Chem 1991, 266(23):15384-15390.

36. Hu Y, Leaver SG, Plant GW, Hendriks WT, Niclou SP, Verhaagen J, Harvey AR, Cui Q: Lentiviral-mediated transfer of CNTF to schwann cells within reconstructed peripheral nerve grafts enhances adult retinal ganglion cell survival and axonal regeneration. Mol Ther 2005, 11(6):906-915.

37. Leaver SG, Harvey AR, Plant GW: Adult olfactory ensheathing glia promote the long-distance growth of adult retinal ganglion cell neurites in vitro. Glia 2006, 53(5):467-476.

38. Schwartz M, Yoles E: Immune-based therapy for spinal cord repair: autologous macrophages and beyond. J Neurotrauma 2006, 23(3-4):360-370.

39. Cummings BJ, Uchida N, Tamaki SJ, Salazar DL, Hooshmand M, Summers R, Gage FH, Anderson AJ: Human neural stem cells differentiate and promote locomotor recovery in spinal cord-injured mice. Proc Natl Acad Sci U S A 2005, 102(39):14069-14074.

40. Iwanami A, Kaneko S, Nakamura M, Kanemura Y, Mori H, Kobayashi S, Yamasaki M, Momoshima S, Ishii H, Ando K, Tanioka Y, Tamaoki N, Nomura T, Toyama Y, Okano H: Transplantation of human neural stem cells for spinal cord injury in primates. J Neurosci Res 2005, 80(2):182-190.

41. Koshizuka S, Okada S, Okawa A, Koda M, Murasawa M, Hashimoto M, Kamada T, Yoshinaga K, Murakami M, Moriya H, Yamazaki M: Transplanted hematopoietic stem cells from bone marrow differentiate into neural lineage cells and promote functional recovery after spinal cord injury in mice. J Neuropath and Exp Neurol 2004, 63(1):64-72.

42. Barakat DJ, Gaglani SM, Neravetla SR, Sanchez AR, Andrade CM, Pressman Y, Puzis R, Garg MS, Bunge MB, Pearse DD: Survival, integration, and axon growth support of glia transplanted into the chronically contused spinal cord. Cell Transplant 2005, 14(4):225-240.

43. Sasaki M, Lankford KL, Zemedkun M, Kocsis JD: Identified olfactory ensheathing cells transplanted into the transected dorsal funiculus bridge the lesion and form myelin. J Neurosci 2004, 24(39):8485-8493.

44. Hill CE, Moon LD, Wood PM, Bunge MB: Labeled Schwann cell transplantation: cell loss, host Schwann cell replacement, and strategies to enhance survival. Glia 2006, 53(3):338-343.

45. Beattie MS, Bresnahan JC, Komon J, Tovar CA, Van Meter M, Anderson DK, Faden Al, Hsu CY, Noble L, Salzman S, Young W: Endogenous repair after spinal cord contusion injuries in the rat. Exp Neurol 1997, 148(2):453-463.

46. Boruch AV, Conners JJ, Pipitone M, Deadwyler G, Storer PD, Devries GH, Jones KJ: Neurotrophic and migratory properties of an olfactory ensheathing cell line. Glia 2001, 33(3):225-229.

47. Cao L, Liu L, Chen ZY, Wang LM, Ye JL, Qiu HY, Lu CL, He C: Olfactory ensheathing cells genetically modified to secrete GDNF to promote spinal cord repair. Brain 2004, 127(3):535-549.

48. Woodhall E, West AK, Chuah MI: Cultured olfactory ensheathing cells express nerve growth factor brain-derived neurotrophic factor glia cell line-derived neurotrophic factor and their receptors. Brain Res Mol Brain Res 2001, 88(1-2):203-213.

49. Fairless R, Frame MC, Barnett SC: $\mathrm{N}$-cadherin differentially determines Schwann cell and olfactory ensheathing cell adhesion and migration responses upon contact with astrocytes. Mol Cell Neurosci 2005, 28(2):253-263.

50. Grimpe B, Dong S, Doller C, Temple K, Malouf AT, Silver J: The critical role of basement membrane-independent laminin gamma 1 chain during axon regeneration in the CNS. J Neurosci 2002, 22(8):3144-3160.

51. Tom VJ, Doller CM, Malouf AT, Silver J: Astrocyte-associated fibronectin is critical for axonal regeneration in adult white matter. J Neurosci 2004, 24(42):9282-9290.

52. Horky LL, Galimi F, Gage FH, Horner PJ: Fate of endogenous stem/ progenitor cells following spinal cord injury. J Comp Neurol 2006, 498(4):525-538.

53. Lee $\mid H$, Bulte JW, Schweinhardt $P$, Douglas T, Trifunovski A, Hofstetter $C$, Olson $L$, Spenger $C$ : In vivo magnetic resonance tracking of olfactory ensheathing glia grafted into the rat spinal cord. Exp Neurol 2004, 187(2):509-516.

54. Ramon-Cueto A, Nieto-Sampedro M: Regeneration into the spinal cord of transected dorsal root axons is promoted by ensheathing glia transplants. Exp Neurol 1994, 127(2):232-244

55. Duncan ID, Aguayo AJ, Bunge RP, Wood PM: Transplantation of rat Schwann cells grown in tissue culture into the mouse spinal cord. J Neurol Sci 1981, 49(2):241-252.

56. Symons NA, Danielsen N, Harvey AR: Migration of cells into and out of peripheral nerve isografts in the peripheral and central nervous systems of the adult mouse. Eur J Neurosci 2001, 14(3):522-532.

57. Plant GW, Bates ML, Bunge MB: Inhibitory proteoglycan immunoreactivity is higher at the caudal than the rostral Schwann cell graft-transected spinal cord interface. Mol Cell Neurosci 2001, 17(3):471-487.

58. Doucette R: Glial cells in the nerve fiber layer of the main olfactory bulb of embryonic and adult mammals. Microsc Res Tech 1993, 24(2):113-130.

59. Lemke G: Glial control of neuronal development. Ann Rev Neurosci 2001 , 24:87-105

60. Ruitenberg MJ, Vukovic J, Blomster L, Hall JM, Jung S, Filgueira L, McMenamin PG, Plant GW: CX3CL1/fractalkine regulates branching and migration of monocyte-derived cells in the mouse olfactory epithelium. J Neuroimmunol 2008, 205(1-2):80-85.

61. Chinnery HR, Ruitenberg MJ, Plant GW, Pearlman E, Jung S, McMenamin PG: The chemokine receptor CX3CR1 mediates homing of MHC class II-positive cells to the normal mouse corneal epithelium. Invest Ophthalmol Vis Sci 2007, 48(4):1568-1574.

62. Roet KC, Bossers K, Franssen EH, Ruitenberg MJ, Verhaagen J: A metaanalysis of microarray-based gene expression studies of olfactory bulbderived olfactory ensheathing cells. Exp Neurol 2011, 229(1):10-45.

63. Shihabuddin LS, Ray J, Gage FH: FGF-2 is sufficient to isolate progenitors found in the adult mammalian spinal cord. Exp Neurol 1997, 148(2):577-586.

64. McTigue DM, Horner PJ, Stokes BT, Gage FH: Neurotrophin-3 and brainderived neurotrophic factor induce oligodendrocyte proliferation and myelination of regenerating axons in the contused adult rat spinal cord. $J$ Neurosci 1998, 18(14):5354-5365

65. Horner PJ, Power AE, Kempermann G, Kuhn HG, Palmer TD, Winkler J, Thal LJ, Gage FH: Proliferation and differentiation of progenitor cells throughout the intact adult rat spinal cord. J Neurosci 2000, 20(6):2218-2228

66. Lytle JM, Wrathall JR: Glial cell loss proliferation and replacement in the contused murine spinal cord. Eur J Neurosci 2007, 25(6):1711-1724.

67. Yang H, Lu P, McKay HM, Bernot T, Keirstead H, Steward O, Gage FH, Edgerton VR, Tuszynski MH: Endogenous neurogenesis replaces oligodendrocytes and astrocytes after primate spinal cord injury. J Neurosci 2006, 26(8):2157-2166.

68. Adrian EK Jr: Cell division in injured spinal cord. Am J Anat 1968, 123(3):501-520

69. Adrian EK Jr, Williams MG, George FC: Fine structure of reactive cells in injured nervous tissue labeled with $3 \mathrm{H}$-thymidine injected before injury. J Comp Neurol 1978, 180(4):815-839.

70. Kojima A, Tator $\mathrm{CH}$ : Intrathecal administration of epidermal growth factor and fibroblast growth factor 2 promotes ependymal proliferation and functional recovery after spinal cord injury in adult rats. J Neurotrauma 2002, 19(2):223-238.

71. Santos-Silva A, Fairless R, Frame MC, Montague P, Smith GM, Toft A, Riddell JS, Barnett SC: FGF/heparin differentially regulates Schwann cell and olfactory ensheathing cell interactions with astrocytes: a role in astrocytosis. J Neurosci 2007, 27(27):7154-7167. 
72. Goritz C, Dias DO, Tomilin N, Barbacid M, Shupliakov O, Frisen J: A pericyte origin of spinal cord scar tissue. Science 2011, 333(6039):238-242.

73. Decimo I, Bifari F, Rodriguez FJ, Malpeli G, Dolci S, Lavarini V, Pretto S, Vasquez S, Sciancalepore M, Montalbano A, Berton V, Krampera M, Fumagalli G: Nestin- and doublecortin-positive cells reside in adult spinal cord meninges and participate in injury-induced parenchymal reaction. Stem Cells 2011, 29(12):2062-2076.

74. Barnabe-Heider F, Gorit C, Sabelstrom H, Takebayashi H, Pfrieger FW, Meletis $K$, Frisen J: Origin of new glial cells in intact and injured adult spinal cord. Cell Stem Cell 2010, 7(4):470-482.

75. Meletis K, Barnabe-Heider F, Carlen M, Evergren E, Tomilin N, Shupliakov O, Frisen J: Spinal cord injury reveals multilineage differentiation of ependymal cells. PLoS Biol 2008, 6(7):e182.

76. Casella GT, Marcillo A, Bunge MB, Wood PM: New vascular tissue rapidly replaces neural parenchyma and vessels destroyed by a contusion injury to the rat spinal cord. Exp Neurol 2002, 173(1):63-76.

77. Brook GA, Plate D, Franzen R, Martin D, Moonen G, Schoenen J, Schmitt AB, Noth J, Nacimiento W: Spontaneous longitudinally orientated axonal regeneration is associated with the Schwann cell framework within the lesion site following spinal cord compression injury of the rat. $J$ Neurosci Res 1998, 53(1):51-65.

78. Hill CE, Beattie MS, Bresnahan JC: Degeneration and sprouting of identified descending supraspinal axons after contusive spinal cord injury in the rat. Exp Neurol 2001, 171(1):153-169.

79. O'Brien DF, Farrell M, Fraher JP, Bolger C: Schwann cell invasion of the conus medullaris: case report. Eur Spine J 2003, 12(3):328-331.

80. Lakatos A, Barnett SC, Franklin RJ: Olfactory ensheathing cells induce less host astrocyte response and chondroitin sulphate proteoglycan expression than Schwann cells following transplantation into adult CNS white matter. Exp Neurol 2003, 184(1):237-246.

81. Ramon-Cueto A, Avila J: Olfactory ensheathing glia: properties and function. Brain Res Bull 1998, 46(3):175-187.

82. Gueye Y, Ferhat L, Sbai O, Bianco J, Ould-Yahoui A, Bernard A, Charrat E, Chauvin JP, Risso JJ, Feron F, Rivera S, Khrestchatisky M: Trafficking and secretion of matrix metalloproteinase- 2 in olfactory ensheathing glial cells: A role in cell migration? Glia 2011, 59(5):750-770.

83. Li Y, Li D, Raisman G: Interaction of olfactory ensheathing cells with astrocytes may be the key to repair of tract injuries in the spinal cord: the 'pathway hypothesis'. J Neurocytol 2005, 34(3-5):343-351.

84. Tisay KT, Key B: The extracellular matrix modulates olfactory neurite outgrowth on ensheathing cells. J Neurosci 1999, 19(22):9890-9899.

85. Franssen $\mathrm{EH}$, Roet KC, de Bree FM, Verhaagen J: Olfactory ensheathing glia and Schwann cells exhibit a distinct interaction behavior with meningeal cells. J Neurosci Res 2009, 87:1556-1564.

86. Obremski VJ, Johnson MI, Bunge MB: Fibroblasts are required for Schwann cell basal lamina deposition and ensheathment of unmyelinated sympathetic neurites in culture. J Neurocytol 1993, 22(2):102-117.

87. Ibanez C, Ito D, Zawadzka M, Jeffery ND, Franklin RJ: Calponin is expressed by fibroblasts and meningeal cells but not olfactory ensheathing cells in the adult peripheral olfactory system. Glia 2007, 55(2):144-151.

88. Barnett SC, Alexander CL, Iwashita Y, Gilson JM, Crowther J, Clark L, Dunn LT, Papanastassiou V, Kennedy PG, Franklin RJ: Identification of a human olfactory ensheathing cell that can effect transplant-mediated remyelination of demyelinated CNS axons. Brain 2000, 123(8):1581-1588.

89. Boyd JG, Jahed A, McDonald TG, Krol KM, Van Eyk JE, Doucette R, Kawaja MD: Proteomic evaluation reveals that olfactory ensheathing cells but not Schwann cells express calponin. Glia 2006, 53(4):434-440.

90. Li Y, Field PM, Raisman G: Regeneration of adult rat corticospinal axons induced by transplanted olfactory ensheathing cells. J Neurosci 1998, 18(24):10514-10524

91. Lakatos A, Franklin RJ, Barnett SC: Olfactory ensheathing cells and Schwann cells differ in their in vitro interactions with astrocytes. Glia 2000, 32(3):214-225.

92. Trang T, Beggs S, Wan X, Salter MW: P2X4-receptor-mediated synthesis and release of brain-derived neurotrophic factor in microglia is dependent on calcium and p38-mitogen-activated protein kinase activation. J Neurosci 2009, 29(11):3518-3528.

93. Heumann R, Lindholm D, Bandtlow C, Meyer M, Radeke M, Misko TP J,

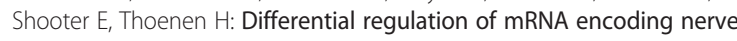
growth factor and its receptor in rat sciatic nerve during development, degeneration, and regeneration: role of macrophages. Proc Natl Acad Sci U S A 1987, 84(23):8735-8739.

94. Meier C, Parmantier E, Brennan A, Mirsky R, Jessen KR: Developing Schwann cells acquire the ability to survive without axons by establishing an autocrine circuit involving insulin-like growth factor neurotrophin-3 and platelet-derived growth factor-BB. J Neurosci 1999, 19(10):3847-3859.

95. Dowsing BJ, Morrison WA, Nicola NA, Starkey GP, Bucci T, Kilpatrick TJ: Leukemia inhibitory factor is an autocrine survival factor for Schwann cells. J Neurochem 1999, 73(1):96-104

96. Edgerton VR, Roy RR: Paralysis recovery in humans and model systems. Curr Opin Neurobiol 2002, 12(6):658-667.

97. Kubasak MD, Jindrich DL, Zhong H, Takeoka A, McFarland KC, Munoz-Quiles C, Roy RR, Edgerton VR, Ramon-Cueto A, Phelps PE: OEG implantation and step training enhance hindlimb-stepping ability in adult spinal transected rats. Brain 2008, 131(Pt 1):264-276.

98. Takeoka A, Kubasak MD, Zhong H, Roy RR, Phelps PE: Serotonergic innervation of the caudal spinal stump in rats after complete spinal transection: effect of olfactory ensheathing glia. J Comp Neurol 2009, 515(6):664-676.

99. Basso DM, Beattie MS, Bresnahan JC: Graded histological and locomotor outcomes after spinal cord contusion using the NYU weight-drop device versus transection. Exp Neurol 1996, 139(2):244-256.

100. Fitch MT, Doller C, Combs CK, Landreth GE, Silver J: Cellular and molecular mechanisms of glial scarring and progressive cavitation: in vivo and in vitro analysis of inflammation-induced secondary injury after CNS trauma. J Neurosci 1999, 19(19):8182-8198.

101. McKeon RJ, Schreiber RC, Rudge JS, Silver J: Reduction of neurite outgrowth in a model of glial scarring following CNS injury is correlated with the expression of inhibitory molecules on reactive astrocytes. J Neurosci 1991, 11(11):3398-3411.

102. Alilain WJ, Horn KP, Hu H, Dick TE, Silver J: Functional regeneration of respiratory pathways after spinal cord injury. Nature 2011, 475(7355):196-200.

103. Bradbury EJ, Moon LD, Popat RJ, King VR, Bennett GS, Patel PN, Fawcett JW, McMahon SB: Chondroitinase ABC promotes functional recovery after spinal cord injury. Nature 2002, 416(6881):636-640.

104. Zufferey R, Dull T, Mandel RJ, Bukovsky A, Quiroz D, Naldini L, Trono D: Selfinactivating lentivirus vector for safe and efficient in vivo gene delivery. J Virol 1998, 72(12):9873-9880.

105. Gruner JA: A monitored contusion model of spinal cord injury in the rat. J Neurotrauma 1992, 9(2):123-126. discussion 126-128.

106. Metz GA, Whishaw IQ: Cortical and subcortical lesions impair skilled walking in the ladder rung walking test: a new task to evaluate foreand hindlimb stepping placing and co-ordination. J Neurosci Meths 2002, 115(2):169-179.

107. Bates KA, Fonte J, Robertson TA, Martins RN, Harvey AR: Chronic gliosis triggers Alzheimer's disease-like processing of amyloid precursor protein. Neuroscience 2002, 113(4):785-796.

108. Oudega M, Vargas CG, Weber AB, Kleitman N, Bunge MB: Long-term effects of methylprednisolone following transection of adult rat spinal cord. Eur J Neurosci 1999, 11(7):2453-2464.

109. West MJ, Slomianka L, Gundersen HJ: Unbiased stereological estimation of the total number of neurons in thesubdivisions of the rat hippocampus using the optical fractionator. Anat Rec 1991, 231(4):482-497.

doi:10.1186/1471-2202-14-106

Cite this article as: Barbour et al:: Tissue sparing, behavioral recovery, supraspinal axonal sparing/regeneration following sub-acute glial transplantation in a model of spinal cord contusion. BMC Neuroscience $201314: 106$ 